\title{
Biases of Global Tropopause Altitude Products in Reanalyses and Implications for Estimates of Tropospheric Column Ozone
}

\author{
Lingyun Meng ${ }^{1}$, Jane Liu ${ }^{2, *}$, David W. Tarasick ${ }^{3}\left(\mathbb{D}\right.$ and Yingjie $\mathrm{Li}^{4}$ \\ 1 School of Atmospheric Sciences, Nanjing University, Nanjing 210023, China; 141170037@smail.nju.edu.cn \\ 2 Department of Geography and Planning, University of Toronto, Toronto, ON M5S 3G3, Canada \\ 3 Air Quality Research Division, Environment and Climate Change Canada, \\ Downsview, ON M3H 5T4, Canada; david.tarasick@canada.ca \\ 4 School of Geography, Geomatics and Planning, Jiangsu Normal University, Xuzhou 221116, China; \\ liyingjie@jsnu.edu.cn \\ * Correspondence: janejj.liu@utoronto.ca
}

check for updates

Citation: Meng, L.; Liu, J.; Tarasick, D.W.; Li, Y. Biases of Global Tropopause Altitude Products in Reanalyses and Implications for Estimates of Tropospheric Column Ozone. Atmosphere 2021, 12, 417. https: / / doi.org/10.3390/ atmos12040417

Academic Editors: Chunlei Liu, Todd R. Jones and Bernhard Rappenglueck

Received: 3 February 2021

Accepted: 17 March 2021

Published: 24 March 2021

Publisher's Note: MDPI stays neutral with regard to jurisdictional claims in published maps and institutional affiliations.

Copyright: (c) 2021 by the authors. Licensee MDPI, Basel, Switzerland. This article is an open access article distributed under the terms and conditions of the Creative Commons Attribution (CC BY) license (https:// creativecommons.org/licenses/by/ $4.0 /)$.

\begin{abstract}
Accuracy of global tropopause altitude products from reanalyses is important to applications of the products, including the derivation of tropospheric column ozone (TCO). Here, monthly biases in lapse-rate tropopause pressure $\left(\mathrm{P}_{\mathrm{LRT}}\right)$ in two reanalyses, NCEP/NCAR and MERRA-2, and associated implications for estimating TCO are examined, based on global radiosonde observations over 1980-2017 at 689 stations. Our analysis suggests that the global mean $\mathrm{P}_{\mathrm{LRT}}$ is underestimated by $-2.3 \mathrm{hPa}$ in NCEP/NCAR and by $-0.9 \mathrm{hPa}$ in MERRA-2, mainly attributable to large negative biases around the subtropics $\left(\sim 20^{\circ}-50^{\circ}\right)$ in both hemispheres, with generally positive biases at other latitudes. Overall, NCEP/NCAR outperforms MERRA-2 in the Northern Hemisphere but underperforms MERRA-2 in the Southern Hemisphere. $\mathrm{P}_{\text {LRT }}$ biases in the two reanalyses vary more evidently with latitude than with longitude. From winter to summer, the peaks of negative $P_{\text {LRT }}$ biases around the subtropics shift poleward by $\sim 10^{\circ}$. Approximately, $70 \%$ of the reanalysis $\mathrm{P}_{\mathrm{LRT}}$ biases are within -10-10 hPa. Consequently, a negative (positive) $\mathrm{P}_{\mathrm{LRT}}$ bias induces a positive (negative) TCO bias. In absolute magnitude, the mean ozonesonde TCO bias attributable to $\mathrm{P}_{\text {LRT }}$ biases is $\sim 0.2, \sim 0.8$ and $\sim 1.2$ Dobson Units (DU) if a $\mathrm{P}_{\mathrm{LRT}}$ bias is within $0-5,10-15$, and 10-15 hPa. Using a global ozone climatology, we estimate that the global mean bias in TCO induced by the $\mathrm{P}_{\text {LRT }}$ biases in both reanalyses is positive, being $0.64 \mathrm{DU}$ (or $2.2 \%$ ) for NCEP/NCAR and $0.28 \mathrm{DU}$ (or 1.1\%) for MERRA-2.
\end{abstract}

Keywords: tropopause; reanalysis; ozone

\section{Introduction}

As the boundary between the well-mixed convective troposphere and the radiatively controlled stratosphere, the tropopause closely relates to multiple processes in the atmosphere. Long-term changes in tropopause height are thought to be an indicator of climate change [1-3]. Previous studies [1] suggest that an increase in tropopause height is mainly attributable to warming of the troposphere due to an increase in well-mixed greenhouse gases (GHGs) and cooling of the stratosphere due to a reduction in stratospheric ozone and the increase in GHGs. The tropopause height frequency (THF) methodology is frequently used in exploring the long-term widening of the tropical belt [4]. Furthermore, tropopause properties, including height, pressure, and temperature, are strongly related to stratosphere-troposphere exchange (STE). Changes in tropopause temperature, especially in the tropics, could substantially affect the transport of water vapor from the troposphere to the stratosphere [5-7]. The determination of the tropopause is a prerequisite for identifying and classifying STE events using trajectory methods [8,9]. The tropopause is also the upper limit for integration of tropospheric properties in chemistry and physics, such as tropospheric column ozone (TCO) $[10,11]$ and tropospheric temperature [12]. Satellite retrievals of stratospheric aerosol optical depths (SAOD) are often presented by integrating 
aerosol loads above the tropopause $[13,14]$. Previous studies have indicated that TCO values are sensitive to the tropopause definition $[15,16]$. In model simulations, different tropopause definitions might lead to $1-12 \%$ variability in TCO values, which can result in a difference in ozone radiative forcing by $5-41 \mathrm{mWm}^{-2}$ [17].

Based on thermal, dynamical, and chemical characteristics of the atmosphere, the tropopause is determined by several criteria. The lapse-rate tropopause (LRT) is the original thermal definition of the tropopause [18], which is widely applied to explore global tropopause variations [19]. The second thermal definition of the tropopause, the cold point tropopause [20], is relevant to water vapor entering the stratosphere from the troposphere in the tropics $[7,21]$. However, the cold point tropopause is reliably coincident with the lapse-rate tropopause only within the deep tropics $\left(20^{\circ} \mathrm{S}-20^{\circ} \mathrm{N}\right)$. The dynamic tropopause is determined by the potential vorticity (PV) threshold (ranges from $\pm 1-4$ PVU, usually \pm 2 PVU) and only applied in the extratropics [22] because PV values converge to zero at the equator. The PV-based tropopause is commonly used for discussing STE events in the extratropics [23]. Thresholds of ozone $\left(\mathrm{O}_{3}\right)$ concentration or of the vertical gradient of $\mathrm{O}_{3}$ concentration are used to determine a chemical tropopause; these thresholds may vary in different latitudes [24]. Overall, the LRT is the most commonly used definition: it is globally applicable, generally consistent with other definitions (where they are valid), and can be determined unambiguously from individual temperature profiles [25,26] except at times in Antarctic winter [27].

Accurate determination of the tropopause is possible from radiosonde data [28], which provide thermodynamic profiles of the atmosphere from the near surface up to $30 \mathrm{~km}$ since the 1900s. However, the limited spatial coverage and temporal inhomogeneities of radiosonde stations are notable, and hamper assessment of the latitude-longitude variations of the global tropopause. A new observational dataset, the Global Positioning System (GPS) radio occultation (RO) data, provides atmospheric parameter profiles with high accuracy and global coverage, since the late 1990s. Previous studies have explored the spatiotemporal structure of the global tropopause on various timescales based on the GPS RO data [29-31].

Alternatively, reanalysis data, which provide global coverage of the tropopause for long-term periods, have been widely used in numerous applications for evaluating tropopause characteristics globally [2,3,32-34] and exploring the relationship between the tropopause and other variables such as $\mathrm{O}_{3}[35,36]$. Some reanalysis data contain LRT data, which are routinely posted online, such as NCEP/NCAR reanalysis (the National Centers for Environmental Prediction/National Center for Atmospheric Research Reanalysis 1) [37], while others only provide atmospheric thermal profiles, from which users can derive the LRT themselves. However, the reanalysis data usually suffers from coarse vertical resolution compared with observational data. Therefore, reanalysis data may underestimate the sharpness of the tropopause [38,39], miss double tropopauses [40], and cause biases in estimates of tropopause properties [41]. Previous studies suggested that coarse vertical resolutions near the UTLS in reanalyses can greatly impact accuracy in determination of the tropopause $[40,41]$. In the tropics, tropopause pressure and temperature in NCEP/NCAR reanalysis have been found to be overestimated by $2-5 \mathrm{hPa}$ and by $3-5 \mathrm{~K}$, respectively, in comparison with radiosonde data for 1979-1997 [42]. Xian and Homeyer [40] studied four reanalysis datasets and found that the largest biases of LRT in these data appear in the subtropics $\left(20^{\circ}-45^{\circ}\right)$ of each hemisphere. In their study, LRT is estimated from atmospheric thermal profiles in these reanalysis data [40]. In addition, different reanalysis LRT data can produce inconsistent values of tropopause properties [40-42]. As biases in reanalysis LRT would be passed to applications of these LRT data, such as in estimating TCO and STE mass fluxes, the LRT biases should be assessed thoroughly to provide confidence and appropriate cautions for usage of reanalysis LRT data.

As reanalyses are often regridded into different horizontal resolutions for different applications $[40,43]$, whether LRT biases in a reanalysis dataset vary with its horizontal resolution is also a question to address. In many applications, it is necessary to identify the 
layer containing the tropopause in a profile of interest with a certain vertical resolution. Examples of such profiles include vertical temperature and ozone mixing ratio. LRT biases in reanalyses may cause misidentification of the tropopause layer. It is important to analyze how the misidentification rate varies with LRT biases and the vertical resolutions of the profile.

The tropopause is the upper limit for integration of TCO, and is therefore a prerequisite for estimating TCO. However, how large are the TCO biases induced from the LRT biases in reanalyses? How do the induced TCO biases vary spatially? Would the global mean TCO be overestimated or underestimated due to the LRT biases? These questions are worthy of investigation. An assessment of the LRT bias is useful to separating this bias from the overall bias for an estimation of TCO. Fishman et al. [44] and Ziemke et al. [45] developed the tropospheric ozone residual method to derive TCO based on satellite observations, by subtracting the stratospheric column ozone from the total column ozone. In this method, the information on the tropopause also is a critical prerequisite. TCO values are relevant to estimating the global tropospheric ozone burden and the tropospheric ozone radiative forcing [17,46-48], further suggesting the importance of assessing the induced TCO biases. Such assessments are also useful to wide applications of TCO data, for example, in data assimilation studies [49].

This study aims to address the above-discussed questions. Through comparison with radiosonde observations, we characterize the biases in global LRT data in two reanalyses, NCEP/NCAR and the National Aeronautics and Space Administration Modern-Era Retrospective analysis for Research and Applications, version 2 (MERRA-2), over 1980-2017 (Section 3.1). We examine how changes in horizontal resolution in the reanalyses affect LRT biases (Section 3.2). We quantify how LRT biases affect the identification of the tropopause layer in a vertical profile of interest (Section 3.2). Finally, we analyze the TCO biases induced from using the reanalysis $\mathrm{P}_{\mathrm{LRT}}$ as the upper integration limit (Section 3.3). The radiosonde, reanalysis, and ozone data are introduced in Section 2, and conclusions are provided in Section 4.

\section{Materials and Methods}

\subsection{Tropopause Data from Radiosonde Data}

Radiosonde observations used in this study were acquired from the Integrated Global Radiosonde Archive (version 2, IGRA 2), which provides historical sounding records at over 2700 stations globally [50]. We selected 689 radiosonde stations with reasonably complete and recently updated sounding records over 1980-2017. Each station selected for analysis satisfies the criteria that the station still reports data after 2014 (inclusive) and has at least 10,000 archived soundings. Figure 1 shows the number of selected stations in each $10^{\circ}$ latitudinal zone.

The method of Zängl and Hoinka [27] was applied to detect LRT based on the geopotential height, pressure, and temperature profiles provided by the radiosonde data. The first lapse-rate tropopause is defined as "the lowest level at which the lapse rate decreases to $2{ }^{\circ} \mathrm{C} / \mathrm{km}$ or less, provided also the average lapse rate between this level and all higher levels within $2 \mathrm{~km}$ does not exceed $2^{\circ} \mathrm{C} / \mathrm{km}$ " [18]. A secondary tropopause is detected "if above the first tropopause the average lapse rate between any level and all higher levels within $1 \mathrm{~km}$ exceeds $3{ }^{\circ} \mathrm{C} / \mathrm{km}$, then a second tropopause is defined by the same criterion". In this paper, the tropopause height and the corresponding pressure refer to the first LRT height $\left(\mathrm{H}_{\mathrm{LRT}}\right)$ and the first LRT pressure $\left(\mathrm{P}_{\mathrm{LRT}}\right)$ unless stated otherwise. To avoid unrealistic $\mathrm{P}_{\text {LRT }}$ and $\mathrm{H}_{\mathrm{LRT}}$ detected in some soundings, a calculated $\mathrm{P}_{\mathrm{LRT}}$ or $\mathrm{H}_{\mathrm{LRT}}$ in a sounding was regarded as invalid if (1) the $\mathrm{H}_{\mathrm{LRT}}$ is lower than $5 \mathrm{~km}\left(\sim 550 \mathrm{hPa}\right.$ for $\left.\mathrm{P}_{\mathrm{LRT}}\right)$ or higher than $18 \mathrm{~km}\left(\sim 75 \mathrm{hPa}\right.$ for $\left.\mathrm{P}_{\mathrm{LRT}}\right)$, or (2) the sounding has no records above $2 \mathrm{~km}$ of the $\mathrm{H}_{\mathrm{LRT}}$, or (3) the $\mathrm{H}_{\mathrm{LRT}}$ exceeds the range of the mean $\mathrm{H}_{\mathrm{LRT}} \pm$ two standard deviations over 1980-2017 at the station. Because both the reanalyses only provide $\mathrm{P}_{\mathrm{LRT}}$ data, we used $\mathrm{P}_{\mathrm{LRT}}$, instead of $\mathrm{H}_{\mathrm{LRT}}$, from radiosondes to reduce interpolation errors for direct comparisons between radiosonde and reanalysis $\mathrm{P}_{\mathrm{LRT}}$. In Table 1, we provide assessments of both $\mathrm{P}_{\mathrm{LRT}}$ and $\mathrm{H}_{\mathrm{LRT}}$ 
biases on hemispheric and global scales. The $\mathrm{H}_{\mathrm{LRT}}$ biases (Table 1) are converted from $\mathrm{P}_{\mathrm{LRT}}$ biases based on the hydrostatic equation.

Following the criteria set by Seidel and Randel [28], we calculate a monthly PLRT $_{\text {only }}$ if the daily value of $\mathrm{P}_{\mathrm{LRT}}$ is available on at least 15 days in that month, which is appropriate for balancing temporal homogeneity and completeness of radiosonde soundings. In fact, our result is not sensitive to the selection of the threshold of available daily means (see Appendix A). To compare with the reanalysis data (see Section 2.2), monthly means of $P_{\text {LRT }}$ in radiosonde data were binned into the same longitude-latitude grids as the reanalysis data, before bias analysis (Figures 2-8). That is, the monthly mean $\mathrm{P}_{\text {LRT }}$ at a grid cell was averaged from the monthly means over all stations within the grid cell. The first grid cell center of the gridded dataset was set to $90^{\circ} \mathrm{S}$ in latitude and $180^{\circ} \mathrm{W}$ in longitude minus a half of grid cell size in latitude and longitude.

\subsection{Tropopause Data from Reanalysis Data}

Monthly means of $P_{\text {LRT }}$ are available from the NCEP/NCAR [37] since 1948 and from the MERRA-2 (the National Aeronautics and Space Administration Modern-Era Retrospective analysis for Research and Applications, Version 2) [51] since 1980. In this study, we used the monthly means of $\mathrm{P}_{\text {LRT }}$ over 1980-2017 from these two reanalysis datasets because (1) in these two reanalyses, $\mathrm{P}_{\text {LRT }}$ are directly available, which benefits wide applications of the $\mathrm{P}_{\text {LRT }}$ products. For other reanalyses, users have to derive $\mathrm{P}_{\text {LRT }}$ from the reanalysis thermal profile data by themselves, like in Xian and Homeyer [40]; (2) using $P_{\text {LRT }}$ directly reduces calculation errors in deriving $P_{\text {LRT }}$ from the thermal profile data.

The NCEP/NCAR reanalysis is produced with a global spectral model with T62 horizontal resolution and 28 vertical sigma levels [37], while the MERRA-2 is produced with version 5.12.4 of the GEOS atmospheric data assimilation system [51] using a finite-volume dynamical core [52] at a horizontal resolution of $0.5^{\circ} \times 0.625^{\circ}$ and 72 hybrid-eta levels from the surface to $0.01 \mathrm{hPa}$. NCEP/NCAR $\mathrm{P}_{\text {LRT }}$ is derived only partly following the WMO definition, as the thickness criterion is not applied [53]. NCEP/NCAR P LRT $_{\text {data }}$ have been used in a wide range of applications $[3,11,54]$. The upper and lower limits allowed for $\mathrm{P}_{\mathrm{LRT}}$ in the NCEP/NCAR calculation are 450 and $85 \mathrm{hPa}$. Kalnay et al. [37] reported that $\mathrm{P}_{\mathrm{LRT}}$ is placed in the " $\mathrm{A}$ " (first) class of reliability in the reanalysis, suggesting that NCEP/NCAR $P_{\text {LRT }}$ data are more influenced by the observations than by the assimilation. Nevertheless, there are still $\mathrm{P}_{\mathrm{LRT}}$ biases in NCEP/NCAR $\mathrm{P}_{\mathrm{LRT}}$, as reported in the literature [42]. NCEP/NCAR and MERRA-2 provide data, respectively, on grids of $2.5^{\circ} \times 2.5^{\circ}$ and $0.625^{\circ} \times 0.5^{\circ}$ in longitude and latitude. In the upper troposphere-lower stratosphere (UTLS) region, the vertical resolutions are $\sim 1.5-2 \mathrm{~km}$ for NCEP/NCAR and $\sim 1.1 \mathrm{~km}$ for MERRA-2 [55]. To examine biases in $\mathrm{P}_{\text {LRT }}$ under different horizontal resolutions, we remapped $\mathrm{P}_{\mathrm{LRT}}$ from the original resolution in each of the reanalyses to different resolutions, which are $1^{\circ} \times 1^{\circ}$ and $5^{\circ} \times 5^{\circ}$ for NCEP/NCAR data and $1^{\circ} \times 1^{\circ}, 2.5^{\circ} \times 2.5^{\circ}$, and $5^{\circ} \times 5^{\circ}$ for MERRA-2 data. We remapped the $\mathrm{P}_{\text {LRT }}$ value for a grid cell from the $\mathrm{P}_{\text {LRT }}$ values at all the nearest neighbor grid cells, following the distance-weighted method. The Climate Data Operators (CDO) software (https: / / code.mpimet.mpg.de/projects /cdo/files, accessed on 14 October 2020) is used to perform the remapping. Note that the grid cell centers of the reanalysis datasets on the original or other resolutions were also adjusted to be consistent with the radiosonde data before the bias analysis (see Section 2.1).

To assess mean $\mathrm{P}_{\text {LRT }}$ biases globally and by hemisphere, cosine-weighted latitudinal averages are taken at $10^{\circ}$ latitudinal intervals. In this way, the impact of spatial inhomogeneity of radiosonde data on the global and hemispheric means is minimized. The corresponding standard deviations are calculated in the same way.

\subsection{Ozone Data and Derivation of TCO}

To derive TCO at a grid cell, the following data at that grid cell are needed: the ozone profile, the pressure profile, and the $\mathrm{P}_{\mathrm{LRT}}$. We used two sets of ozone profile data. The first is from the global ozonesonde stations, available from the World Ozone and Ultravi- 
olet Radiation Data Centre (WOUDC). Most of the profiles are from the electrochemical concentration cell (ECC)-type ozonesonde, which was introduced in the early 1970s and adopted by a majority of stations in the global network by the early 1980s. The original ozone profiles over 1980-2008 with various vertical resolutions were uniformly processed to $1-\mathrm{km}$ vertical resolution and ozone volume mixing ratio was calculated for each of the 1-km layers from the sea level. A monthly mean of ozone volume mixing ratio in a layer was calculated only if one or more ozonesonde data are available in that layer and month. Accordingly, pressure profiles were processed at 1-km vertical resolution from radiosonde data. We used the reanalysis $\mathrm{P}_{\mathrm{LRT}}$ at their original horizontal resolutions, which are $2.5^{\circ} \times 2.5^{\circ}$ for NCEP $/ \mathrm{NCAR}$ and $0.625^{\circ} \times 0.5^{\circ}$ for MERRA-2 (longitude $\times$ latitude). To be consistent with horizontal resolution of the reanalyses, all data, including ozonesonde profiles, radiosonde pressure profiles and radiosonde $\mathrm{P}_{\mathrm{LRT}}$ were gridded to $2.5^{\circ} \times 2.5^{\circ}$ for NCEP $/$ NCAR and $0.625^{\circ} \times 0.5^{\circ}$ for MERRA-2 (longitude $\times$ latitude). In this processing, the mean of a variable at the corresponding grid cell was taken from one or more data points within that grid cell. Using the same ozone profile and radiosonde pressure profile at a grid cell, we can derive TCO at that grid cell using the $\mathrm{P}_{\mathrm{LRT}}$ value from the radiosonde and from one of the reanalyses, such as NCEP/NCAR. Therefore, the TCO bias is only attributable to the $\mathrm{P}_{\mathrm{LRT}}$ bias in that reanalysis. In a given month, the TCO bias at a grid cell can be assessed only if ozonesonde, radiosonde, and reanalysis data are all available at the grid cell. The number of available monthly samples are 6423 for NCEP/NCAR and 4679 for MERRA-2, as the horizontal resolution of NCEP/NCAR is coarser than that of MERRA-2.

Considering the limited spatial and temporal coverages of the ozonesonde data, we also used the second set of ozone profile data, which are the gridded ozone profiles from the Trajectory-mapped Ozonesonde dataset for the Stratosphere and Troposphere (TOST) over 1980-2012. This is derived from ozone soundings using a trajectory-based ozone mapping methodology [56]. The trajectory-mapping approach is an effective method for interpolating sparse ozonesonde measurements [56,57]. TOST provides monthly means of ozone volume mixing ratio binned into grids of $5^{\circ} \times 5^{\circ} \times 1 \mathrm{~km}$ (latitude, longitude, altitude) from sea level up to $26 \mathrm{~km}$. For consistency with TOST data, we regridded the $\mathrm{P}_{\text {LRT }}$ from the two reanalyses on grids of $5^{\circ} \times 5^{\circ}$ (longitude, latitude). This $5^{\circ} \times 5^{\circ}$ resolution for $\mathrm{P}_{\mathrm{LRT}}$ has a minor effect on the comparison between radiosonde and reanalysis data (see Section 3.2). We followed the procedure described in Section 2.1 to derive monthly means of vertical pressure profile on grids of $5^{\circ} \times 5^{\circ} \times 1 \mathrm{~km}$ (latitude, longitude, altitude) from radiosonde data. Using TOST data, we calculated the monthly mean TCO at grids only if ozone mixing ratios are available at over $80 \%$ of the vertical layers from surface to the tropopause at these grids. In the TCO calculation, the $\mathrm{P}_{\mathrm{LRT}}$ from radiosonde and from the two reanalyses were used respectively, while the vertical ozone and pressure profiles are the same. Therefore, the biases in reanalysis- $\mathrm{P}_{\text {LRT }}$-based TCO are induced by the $\mathrm{P}_{\mathrm{LRT}}$ biases in the reanalyses only.

\section{Results}

\subsection{Spatial and Seasonal Variations in $P_{L R T}$ Biases}

To evaluate $\mathrm{P}_{\text {LRT }}$ biases in NCEP/NCAR and MERRA-2, we compared the monthly mean $\mathrm{P}_{\mathrm{LRT}}$ between the radiosonde and each of the reanalyses at their original horizontal resolutions. Figure 1 shows the climatological $P_{\text {LRT }}$ variation with latitude, based on all radiosonde data from 1980-2017. Although stations are predominantly located in the mid-latitudes of the Northern Hemisphere $(\mathrm{NH})$, the latitudinal structure of $\mathrm{P}_{\mathrm{LRT}}$ is well depicted globally. The climatological $\mathrm{P}_{\mathrm{LRT}}$ increases from $\sim 100 \mathrm{hPa}$ around the equator to $\sim 300 \mathrm{hPa}$ near the polar regions, consistent with the latitudinal variation in the literature from reanalyses [2], GPS radio occultation [58], and radiosonde data [28]. 


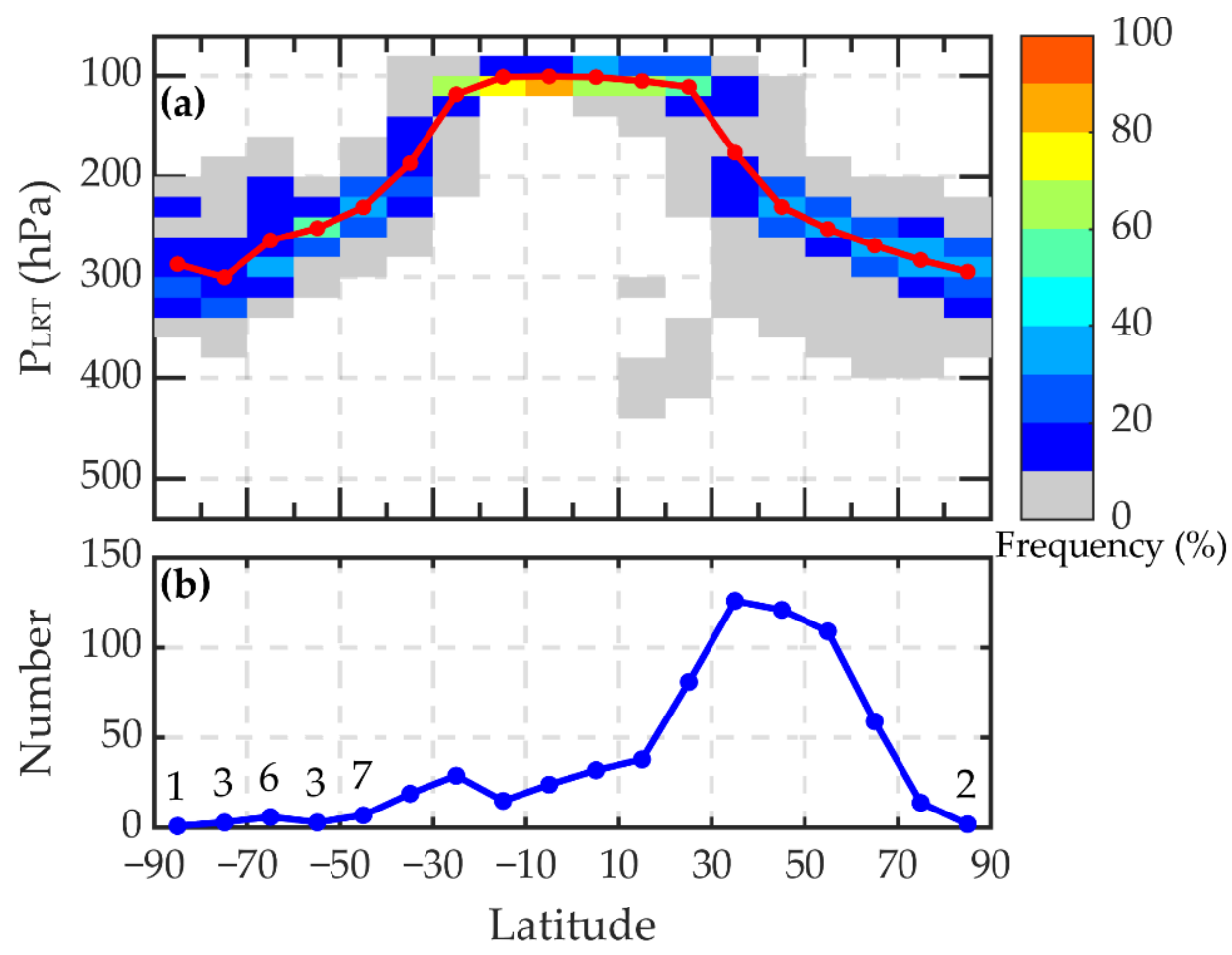

Figure 1. (a) The red line shows the latitudinal variation in the climatological lapse-rate tropopause pressure $\left(\mathrm{P}_{\mathrm{LRT}}\right)$ averaged over 1980-2017. The colors show occurrence frequency of different $\mathrm{P}_{\mathrm{LRT}}$ intervals in each latitudinal bin at selected radiosonde stations. The pressure altitude ranges from 500-100 hPa. (b) The number of the selected stations varying with latitude.

NCEP/NCAR pioneered development of reanalysis data so that the NCEP/NCAR reanalysis has the longest temporal coverage (1948-present). Figure 2 shows that $P_{\text {LRT }}$ in NCEP/NCAR is usually overestimated by $0.5-5.5 \mathrm{hPa}$ in the tropics $\left(20^{\circ} \mathrm{S}-20^{\circ} \mathrm{N}\right)$ and at high latitudes of the $\mathrm{NH}\left(60^{\circ}-90^{\circ} \mathrm{N}\right)$. In the tropics, positive $\mathrm{P}_{\mathrm{LRT}}$ biases of $2-6 \mathrm{hPa}$ in NCEP/NCAR were found by Randel et al. [42], associated with a tropopause temperature overestimated by $3-5 \mathrm{~K}$. In the subtropics $\left(\sim 20^{\circ}-50^{\circ}\right)$ of each hemisphere, $\mathrm{P}_{\mathrm{LRT}}$ in NCEP/NCAR is underestimated, and the bias reaches $\sim 14 \mathrm{hPa}$ around $30^{\circ}-40^{\circ} \mathrm{S}$. In MERRA-2, the largest biases of $P_{\text {LRT }}$ occur in the subtropics, consistent with the maximum biases of $\mathrm{H}_{\mathrm{LRT}}$ found there by Xian and Homeyer [40]. This is the location of the "tropopause break", a sharp discontinuity in the first lapse-rate tropopause, found near the subtropical jets at roughly $30^{\circ} \mathrm{S}$ and $30^{\circ} \mathrm{N}$ (also evident in Figure 1). The subtropics in both hemispheres are transition zones where $P_{\text {LRT }}$ values are remarkably sensitive to the location and intensity of the subtropical jets since the steepest gradients of $P_{\text {LRT }}$ are near the jets $[2,19]$.

A notable negative bias of about $-20 \mathrm{hPa}$ appears in the south polar region $\left(70^{\circ}-80^{\circ} \mathrm{S}\right)$ in NCEP/NCAR. The accuracy of $\mathrm{P}_{\mathrm{LRT}}$ at high latitudes of the Southern Hemisphere (SH) in MERRA-2, which was first released in 2015, is apparently much better. As a result, the mean $\mathrm{P}_{\mathrm{LRT}}$ bias over the $\mathrm{SH}$ is $-4.00 \pm 5.64 \mathrm{hPa}$ in NCEP/NCAR, in comparison with $-0.49 \pm 3.6 \mathrm{hPa}$ in MERRA-2 (Table 1). However, the mean $\mathrm{P}_{\mathrm{LRT}}$ bias over the $\mathrm{NH}$ is $-0.57 \pm 6.04 \mathrm{hPa}$ in NCEP/NCAR, smaller than the mean value of $-1.34 \pm 9.83$ in MERRA-2. Overall, the global mean $\mathrm{P}_{\mathrm{LRT}}$ bias is $-2.28 \pm 5.84 \mathrm{hPa}$ in NCEP/NCAR and $-0.92 \pm 6.71 \mathrm{hPa}$ in MERRA-2 over 1980-2017 (Table 1). Correspondingly, the global $\mathrm{H}_{\mathrm{LRT}}$ is overestimated by $52 \mathrm{~m}$ in NCEP/NCAR and $16 \mathrm{~m}$ in MERRA-2. Therefore, for applications of $\mathrm{P}_{\text {LRT }}$ products, MERRA-2 may be a better choice between the two reanalyses on the global scale, whereas by hemisphere, NCEP/NCAR outperforms MERRA-2 in the $\mathrm{NH}$ but underperforms MERRA-2 in the SH. $\mathrm{P}_{\text {LRT }}$ biases vary much more with latitude than with longitude in both reanalyses. 

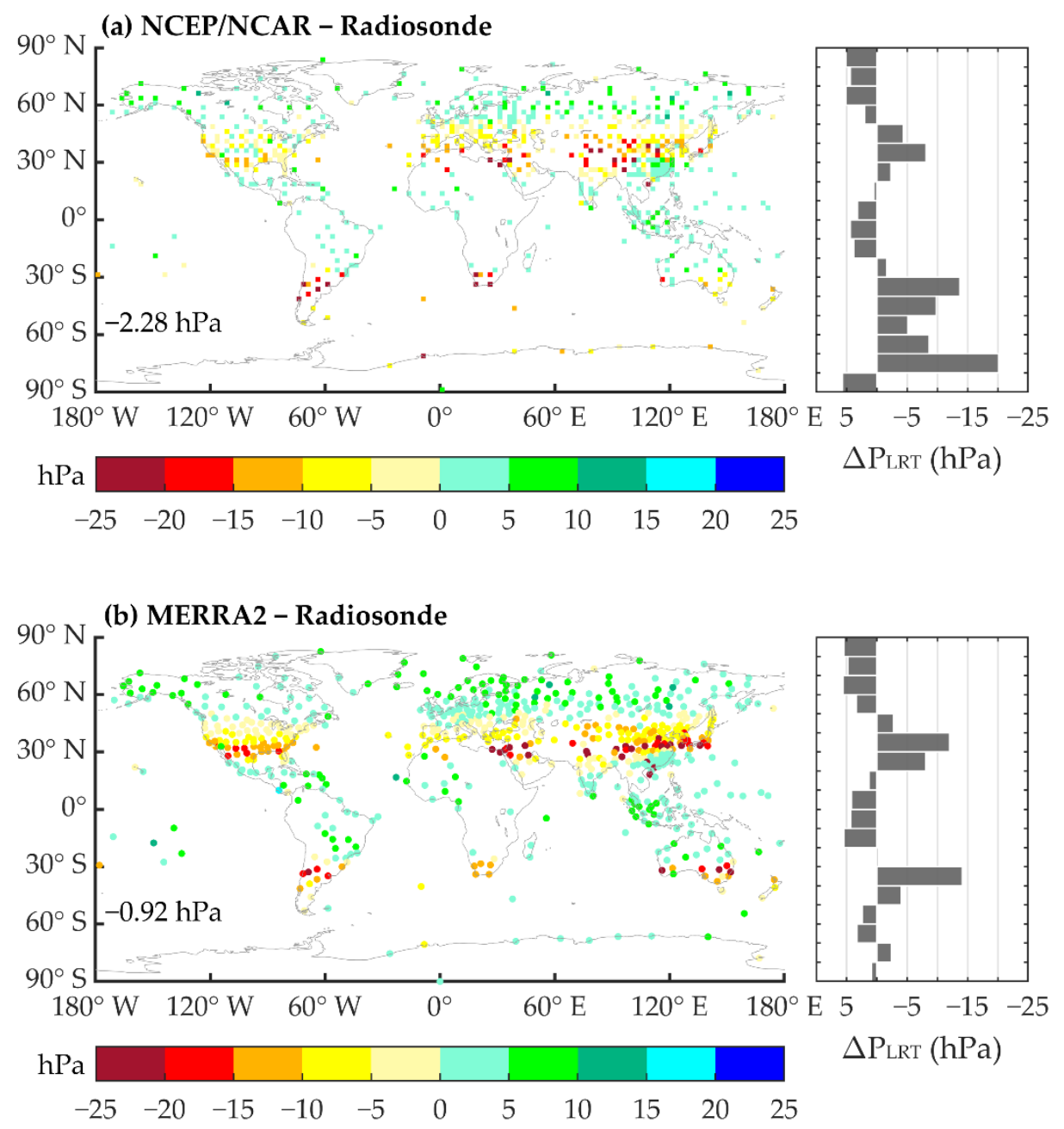

Figure 2. (a) Spatial variation in the $\mathrm{P}_{\mathrm{LRT}}$ difference $\left(\triangle \mathrm{P}_{\mathrm{LRT}}\right.$, in $\left.\mathrm{hPa}\right)$ between NCEP/NCAR and radiosonde data. Each value is the mean difference in $\mathrm{P}_{\mathrm{LRT}}$ over 1980-2017 at each grid cell containing one or more radiosonde sites. In the right panel, $10^{\circ}$ zonal-mean differences are shown. The text indicates the global mean bias. (b) The same as (a), but for the $P_{\text {LRT }}$ difference between MERRA-2 and radiosonde data. $0.625^{\circ} \times 0.5^{\circ}$ grid cells are properly magnified for visibility. The NCEP/NCAR and MERRA-2 data are used in their original resolutions of $2.5^{\circ} \times 2.5^{\circ}$ and $0.625^{\circ} \times 0.5^{\circ}$ in longitude and latitude.

Figure $3 a, b$ shows how the occurrence frequencies of positive and negative $P_{\text {LRT }}$ biases vary with latitude. The most extreme negative biases (below $-20 \mathrm{hPa}$ ) appear most frequently $(\sim 30-40 \%)$ around $30^{\circ}-40^{\circ} \mathrm{S}$, where the mean negative biases peak $(\sim 14 \mathrm{hPa}$, see Figure 2). From $60^{\circ}-90^{\circ} \mathrm{S}$, the distribution of $\mathrm{P}_{\mathrm{LRT}}$ biases is more varied and extreme biases (over $20 \mathrm{hPa}$ or below $-20 \mathrm{hPa}$ ) appear more frequently in NCEP/NCAR than in MERRA-2, indicating better $\mathrm{P}_{\text {LRT }}$ estimates in MERRA-2 for this region. Surprisingly, for NCEP/NCAR $P_{\text {LRT }}$, most extreme biases are negative in the nine stations between $60^{\circ} \mathrm{S}$ and $80^{\circ} \mathrm{S}$ but positive at the Amundsen-Scott station located at $90^{\circ} \mathrm{S}$. Except for $60^{\circ}-90^{\circ} \mathrm{S}$ in the NCEP/NCAR, and the subtropics in the two reanalyses, most $P_{\text {LRT }}$ biases fall into a range from $-10 \mathrm{hPa}$ to $10 \mathrm{hPa}$ at the remaining latitudes (Figure 3a,b). Additionally, positive $\mathrm{P}_{\text {LRT }}$ biases appear more frequently $(60-80 \%)$ than negative biases at the remaining latitudes, while the occurrence frequency of negative $\mathrm{P}_{\mathrm{LRT}}$ biases peaks over $30^{\circ}-40^{\circ}$ near the subtropical jet in each hemisphere (Figure 3c,d). Over the globe, positive and negative biases have comparable frequencies $(\sim 50 \%)$ and the negative global mean $P_{\text {LRT }}$ bias (Table 1 ) is attributable to the large negative biases around the subtropical jets. 
Table 1. Means and standard deviations (in brackets) of $\mathrm{P}_{\mathrm{LRT}}$ biases (in hPa, top panel) and $\mathrm{H}_{\mathrm{LRT}}$ biases (in m, bottom panel) over 1980-2017. MAM stands for March-April-May, JJA June-July-August, SON September-October-November, and DJF December-January-February.

\begin{tabular}{|c|c|c|c|c|c|}
\hline Domain & Yearly & MAM & JJA & SON & DJF \\
\hline & \multicolumn{5}{|c|}{ P $_{\text {LRT }}$ Difference (NCEP-Radiosonde, hPa) } \\
\hline Globe & $-2.28(5.84)$ & $-2.87(6.09)$ & $-2.79(6.48)$ & $-2.56(6.9)$ & $-3.08(6.06)$ \\
\hline $\mathrm{NH}$ & $-0.57(6.04)$ & $-1.04(7.57)$ & $-1.91(7.69)$ & $-0.32(6.91)$ & $-0.59(7.76)$ \\
\hline \multirow[t]{2}{*}{$\mathrm{SH}$} & $-4.00(5.64)$ & $-4.74(4.58)$ & $-3.69(5.25)$ & $-4.80(6.9)$ & $-5.56(4.35)$ \\
\hline & \multicolumn{5}{|c|}{ P $_{\text {LRT }}$ Difference (MERRA-2-Radiosonde, hPa) } \\
\hline Globe & $-0.92(6.71)$ & $-2.53(7.89)$ & $-0.07(8.77)$ & $-0.16(7.71)$ & $-3.61(7.78)$ \\
\hline $\mathrm{NH}$ & $-1.34(9.83)$ & $-2.95(12.02)$ & $-0.97(12.09)$ & $-0.24(10.88)$ & $-3.48(11.78)$ \\
\hline \multirow[t]{2}{*}{$\mathrm{SH}$} & $-0.49(3.6)$ & $-2.10(3.69)$ & $0.85(5.4)$ & $-0.09(4.55)$ & $-3.74(3.78)$ \\
\hline & \multicolumn{5}{|c|}{$\mathrm{H}_{\text {LRT }}$ Difference (NCEP-Radiosonde, m) } \\
\hline Globe & $52(232)$ & $116(238)$ & $33(251)$ & $45(267)$ & $138(243)$ \\
\hline $\mathrm{NH}$ & $14(249)$ & $76(297)$ & $29(300)$ & $-20(272)$ & 48 (301) \\
\hline \multirow[t]{2}{*}{$\mathrm{SH}$} & $91(216)$ & 157 (178) & 37 (201) & $111(262)$ & $228(184)$ \\
\hline & \multicolumn{5}{|c|}{ H $_{\text {LRT }}$ Difference (MERRA-2-Radiosonde, m) } \\
\hline Globe & $16(257)$ & $107(291)$ & $-56(319)$ & $-28(287)$ & 159 (292) \\
\hline $\mathrm{NH}$ & $46(365)$ & $150(429)$ & $-21(424)$ & $-25(392)$ & $178(418)$ \\
\hline $\mathrm{SH}$ & $-14(149)$ & $63(151)$ & $-92(214)$ & $-30(182)$ & $141(167)$ \\
\hline
\end{tabular}

(a) NCEP/NCAR - Radiosonde

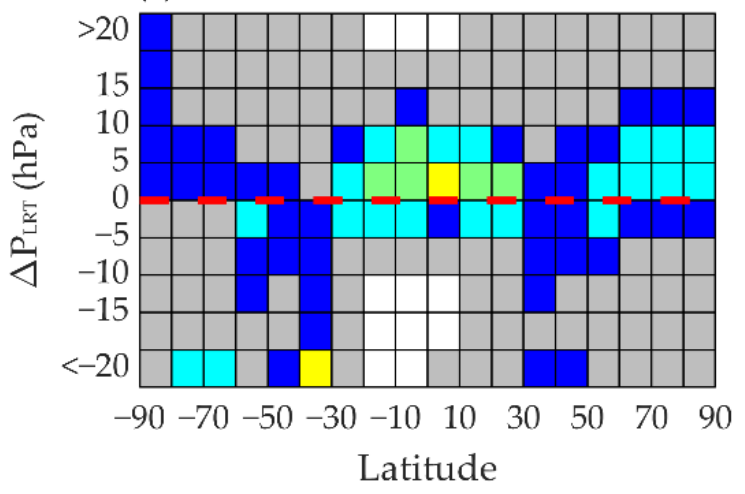

(b) MERRA2 - Radiosonde

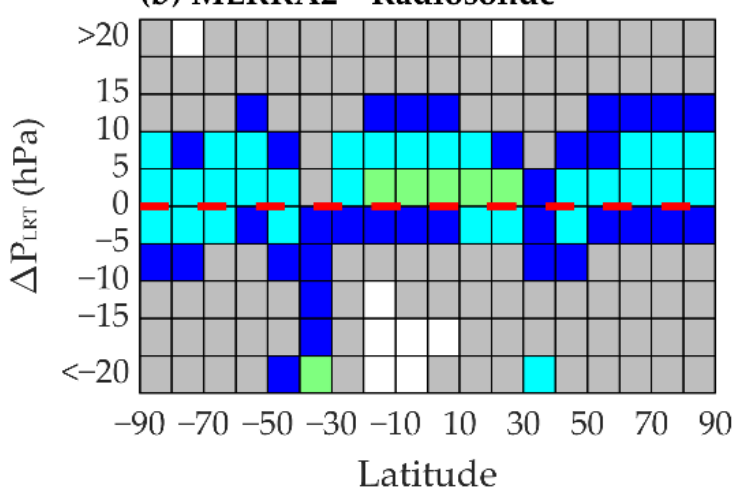

Frequency $(\%)$

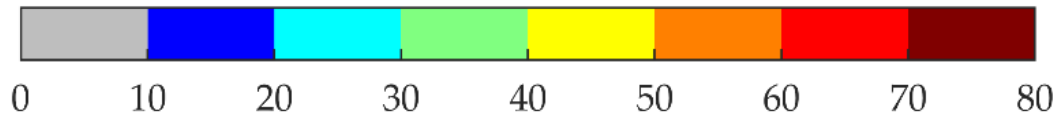

(c) NCEP/NCAR - Radiosonde

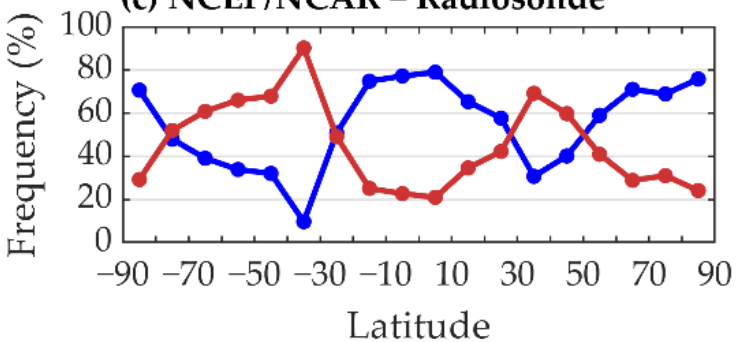

(d) MERRA2 - Radiosonde

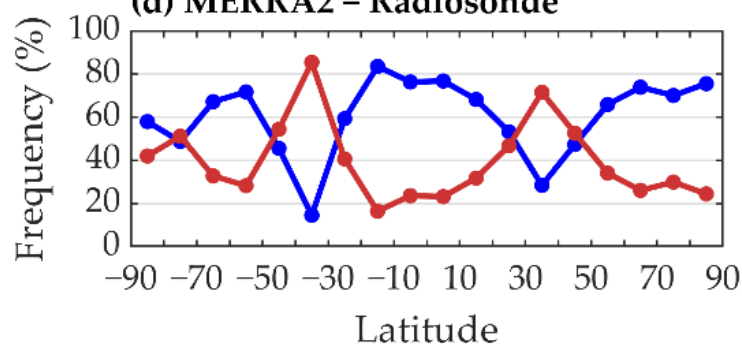

Figure 3. (a) Frequency distribution of the $\mathrm{P}_{\mathrm{LRT}}$ difference $\left(\triangle \mathrm{P}_{\mathrm{LRT}}\right.$, in $\left.\mathrm{hPa}\right)$ between NCEP/NCAR and radiosonde data in each $10^{\circ}$ latitudinal zone. (b) The same as (a), but for the $\mathrm{P}_{\mathrm{LRT}}$ difference between MERRA-2 and radiosonde data. (c) The total frequency of positive biases (in blue) and negative biases (in red) in each $10^{\circ}$ latitudinal band for NCEP/NCAR. (d) The same as (c), but for MERRA-2. The NCEP/NCAR and MERRA-2 data are used in their original resolutions of $2.5^{\circ} \times$ $2.5^{\circ}$ and $0.625^{\circ} \times 0.5^{\circ}$ in longitude and latitude. 
The latitudinal variation of $\mathrm{P}_{\mathrm{LRT}}$ biases by season (Figure 4) is generally similar to that of the annual mean (Figure 2). However, some changes with season are notable. The seasonal variation of $\mathrm{P}_{\mathrm{LRT}}$ biases in each latitudinal zone around the extratropics $\left(20^{\circ}-90^{\circ}\right)$ appears larger in NCER/NCAR than in MERRA-2. In both reanalyses, positive $\mathrm{P}_{\mathrm{LRT}}$ biases in the tropics occur in JJA and SON, while negative $P_{\mathrm{LRT}}$ biases in the subtropics are persistent in all seasons. Around the subtropics, negative $\mathrm{P}_{\mathrm{LRT}}$ biases in MERRA-2 are slightly larger in winter or spring (JJA or SON for the SH; DJF or MAM for the NH), as has been found before for ERA Interim, JRA-55, and CFSR, as well as MERRA-2 [40]. However, the negative bias in NCEP/NCAR maximizes in summer in each hemisphere (DJF for the $\mathrm{SH}$; JJA for the $\mathrm{NH}$ ).

(a) NCEP/NCAR - Radiosonde

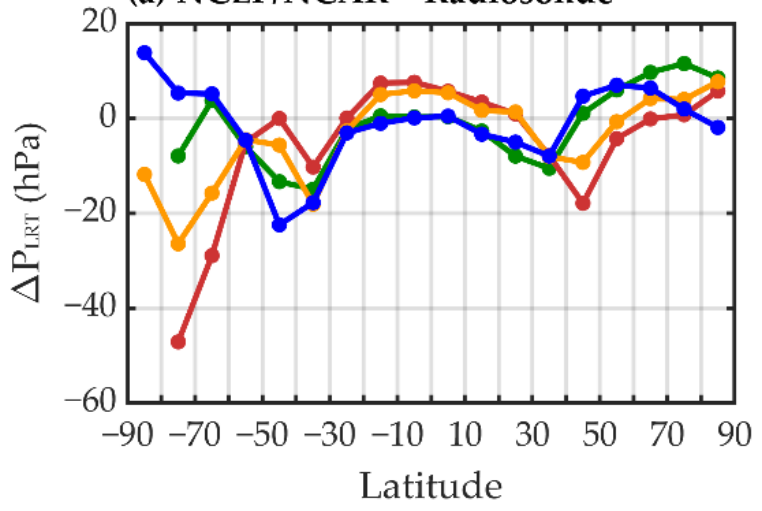

(b) MERRA2 - Radiosonde

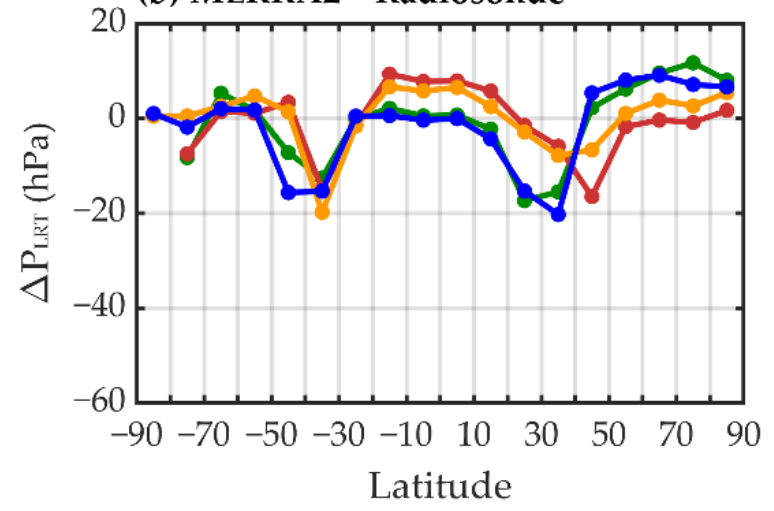

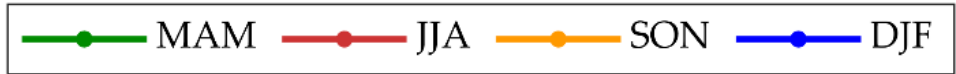

Figure 4. (a) Latitudinal variation in the $\mathrm{P}_{\mathrm{LRT}}$ difference $\left(\triangle \mathrm{P}_{\mathrm{LRT}}\right.$, in $\mathrm{hPa}$ ) between NCEP/NCAR and radiosonde data averaged over 1980-2017 in the four seasons. (b) The same as (a), but for the $\mathrm{P}_{\text {LRT }}$ differences between MERRA-2 and radiosonde data. The NCEP/NCAR and MERRA-2 data are used in their original resolutions of $2.5^{\circ} \times 2.5^{\circ}$ and $0.625^{\circ} \times 0.5^{\circ}$ in longitude and latitude.

Additionally, in summer in each hemisphere, the latitude near the subtropics where negative biases of $\mathrm{P}_{\text {LRT }}$ peak is shifted poleward by $\sim 10^{\circ}$, relative to the latitude where negative biases peak in the corresponding winter. This is associated with the poleward shift of the tropopause breaks in summer over landmasses [43]. In NCER/NCAR, the extreme negative biases over high latitudes in the $\mathrm{SH}$ are most pronounced in winter (JJA) and spring (SON), especially in JJA when the bias is up to $-50 \mathrm{hPa}$. However, such biases are not found in MERRA-2, possibly owing to the assimilation of Microwave Limb Sounder (MLS) stratospheric ozone profiles and Ozone Monitoring Instrument (OMI) column ozone in a system where the assimilated ozone is interactive with radiation [55]. The assimilation of these satellite ozone data improves the representation of ozone profiles in MERRA-2, especially in the SH winter and spring [59-61]. The improved assimilation of ozone profiles in MERRA-2 might correct $\mathrm{P}_{\mathrm{LRT}}$ at high latitudes of the $\mathrm{SH}$ through a modified temperature structure. As a result, the averaged bias over the SH is greatly reduced in MERRA-2, especially in JJA and SON (Table 1).

3.2. $P_{L R T}$ Biases in the Reanalyses at Different Horizontal Resolutions and Implication of $P_{L R T}$ Biases in Misidentification of the Tropopause Layer in Profiles with Different Vertical Resolutions

In applications of reanalysis LRT data, two issues are relevant. The first is whether $\mathrm{P}_{\text {LRT }}$ biases vary with horizontal resolution. To address this question, we regridded $\mathrm{P}_{\text {LRT }}$ to $1^{\circ} \times 1^{\circ}$ and $5^{\circ} \times 5^{\circ}$ from its original $2.5^{\circ} \times 2.5^{\circ}$ resolution in NCER/NCAR, and to $1^{\circ} \times 1^{\circ}, 2.5^{\circ} \times 2.5^{\circ}$, and $5^{\circ} \times 5^{\circ}$ from its original resolution of $0.625^{\circ} \times 0.5$ in MERRA-2, following the distance-weighted method using the Climate Data Operators (CDO) software (see Section 2.2). Figure 5 shows that there is no systematic difference in $P_{\text {LRT }}$ biases in 
either reanalyses remapped into different horizontal resolutions, in terms of the mean over 1980-2017 on a monthly basis. For example, in NCER/NCAR, the $\mathrm{P}_{\mathrm{LRT}}$ bias averaged over all $10^{\circ}$ zones in the $\mathrm{NH}$ is $-1.2,-0.6$, and $-1.3 \mathrm{hPa}$, for $1^{\circ} \times 1^{\circ}, 2.5^{\circ} \times 2.5^{\circ}$ and $5^{\circ} \times 5^{\circ}$ resolutions. At higher resolutions $\mathrm{P}_{\mathrm{LRT}}$ biases show variations at smaller latitudinal intervals and have larger fluctuations, in the $20-40^{\circ}$ latitude band in both hemispheres. This is the case for the NCER/NCAR reanalysis at $1^{\circ} \times 1^{\circ}$ and for MERRA-2 at $0.625^{\circ} \times 0.5^{\circ}$ and $1^{\circ} \times 1^{\circ}$ resolutions.

(a) NCEP/NCAR - Radiosonde

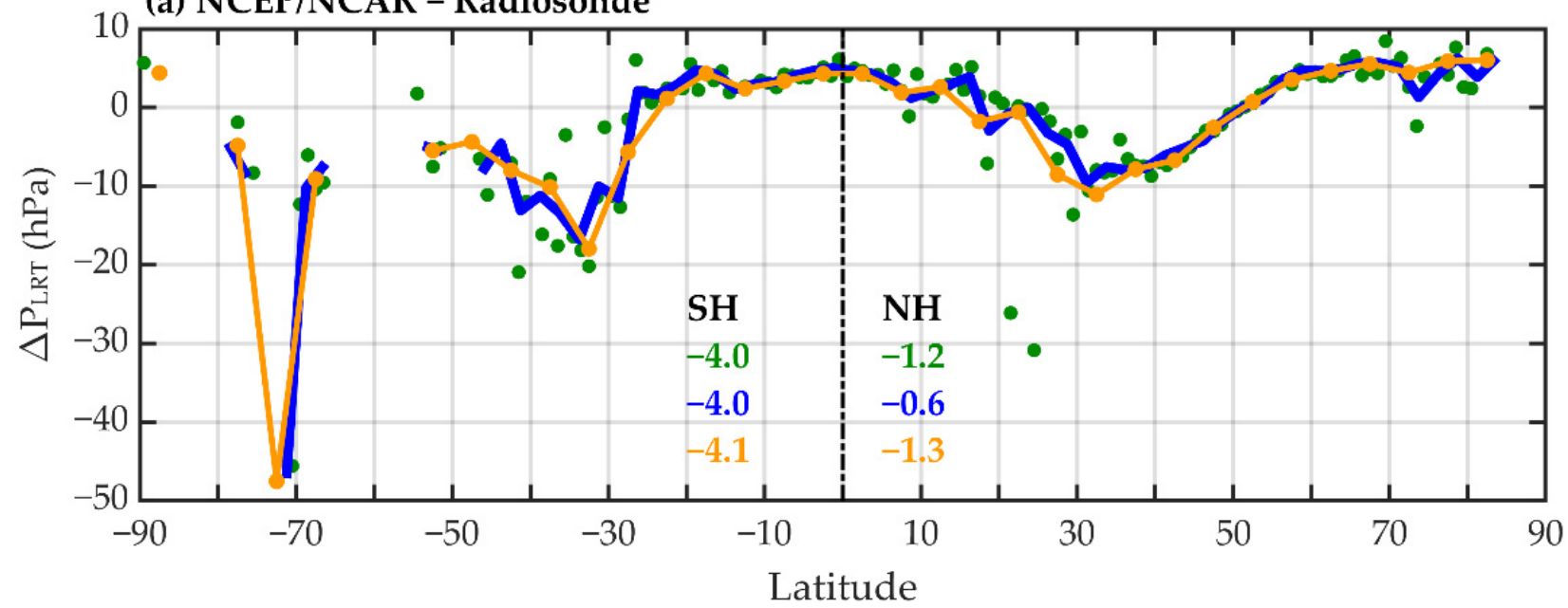

(b) MERRA2 - Radiosonde

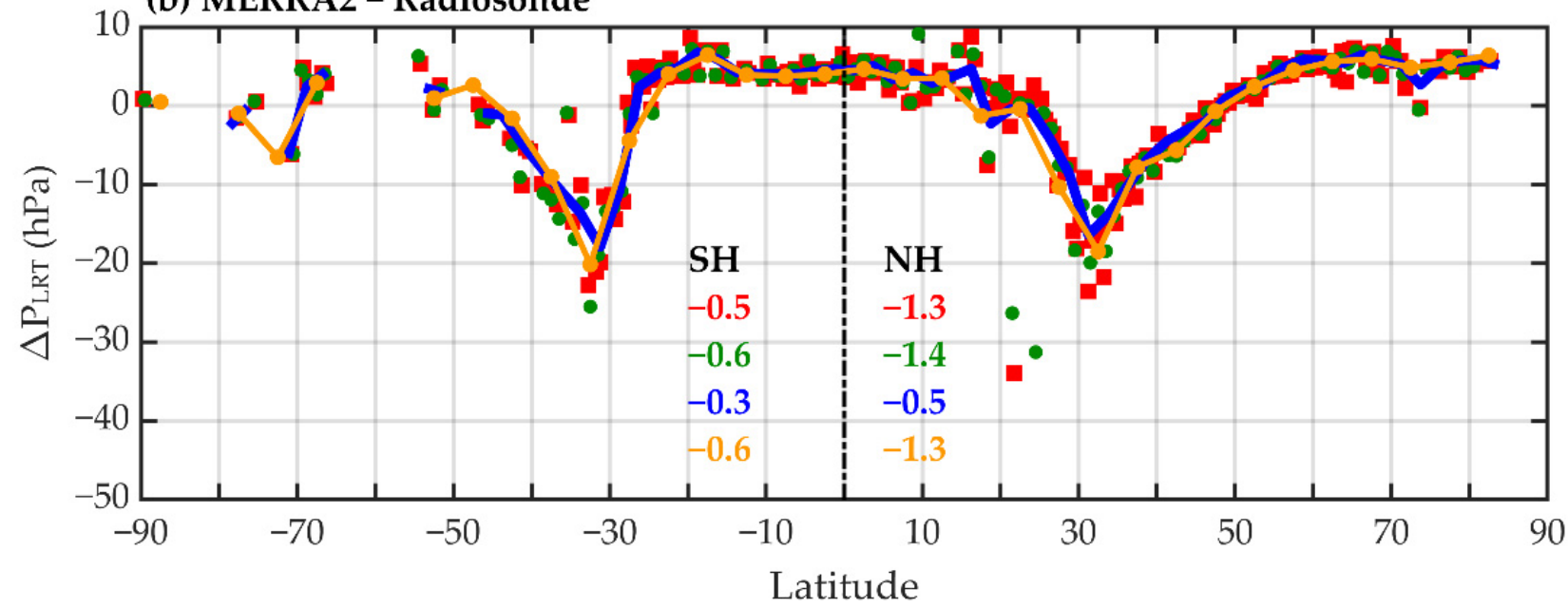

- $0.625^{\circ} \times 0.5^{\circ} \quad-1^{\circ} \times 1^{\circ}$

$2.5^{\circ} \times 2.5^{\circ}$

$5^{\circ} \times 5^{\circ}$

Figure 5. (a) The zonal mean $\mathrm{P}_{\mathrm{LRT}}$ difference $\left(\Delta \mathrm{P}_{\mathrm{LRT}}\right.$, in $\left.\mathrm{hPa}\right)$ over 1980-2017 between NCEP/NCAR and radiosonde data at different horizontal resolutions. The text indicates the hemispheric mean, which is calculated as the cosine-weighted latitudinal average of monthly $10^{\circ}$-zonal mean differences. (b) The same as (a), but for the $P_{\text {LRT }}$ difference between MERRA-2 and radiosonde data.

In NCEP/NCAR, $\mathrm{P}_{\text {LRT }}$ biases are positive in the tropics $\left(20^{\circ} \mathrm{S}-20^{\circ} \mathrm{N}\right)$ and in high latitudes of the $\mathrm{NH}\left(60^{\circ} \mathrm{N}-90^{\circ} \mathrm{N}\right)$ with values close to $5 \mathrm{hPa}$, but are negative in the subtropics in both hemispheres from $20^{\circ}$ to $50^{\circ}$ with the largest negative bias close to $-20 \mathrm{hPa}$ around $30^{\circ} \mathrm{S}$. Additionally, the extreme negative bias of $\sim-50 \mathrm{hPa}$ appears around $70^{\circ} \mathrm{S}$, which is only observed in NCEP/NCAR. $P_{\text {LRT }}$ biases in MERRA-2 vary with latitude, similarly to that in NCEP/NCAR, regardless of horizontal resolution. 
As noted, $\mathrm{P}_{\mathrm{LRT}}$ biases are much reduced in the $\mathrm{SH}$ over $60^{\circ} \mathrm{S}-90^{\circ} \mathrm{S}$ in MERRA-2. Before bias evaluation, the first grid cell center of the reanalysis is adjusted as $90^{\circ} \mathrm{S}\left(180^{\circ} \mathrm{W}\right)$ minus one-half of the grid size in latitude and longitude, for a better match with gridded radiosonde $\mathrm{P}_{\mathrm{LRT}}$. Since the differences in $\mathrm{P}_{\mathrm{LRT}}$ are large between the tropical and polar sides of the tropopause break near the subtropical jet [25], a minor mismatch in the locations of the grids between observational and reanalysis data might lead to incorrect interpretations of $\mathrm{P}_{\text {LRT }}$ biases.

The second relevant issue is the implication of $\mathrm{P}_{\mathrm{LRT}}$ biases in reanalyses for misidentification of the tropopause layer. The vertical profiles of a variable (e.g., ozone mixing ratio or temperature) are often presented in a fixed vertical resolution. In some applications, it is necessary to identify the layer containing the tropopause in such a vertical profile. $P_{\text {LRT }}$ values from reanalyses are often used to make such determinations $[10,13,57]$. The accuracy of the identification will be affected by the magnitude of $\mathrm{P}_{\mathrm{LRT}}$ biases in reanalyses and the vertical resolution of the variable. We use NCEP/NCAR data as an example (Figure 6a); the results from MERRA-2 are similar (Figure 6b). As $P_{\text {LRT }}$ biases vary little with horizontal resolution (Figure 5), we use $\mathrm{P}_{\mathrm{LRT}}$ in NCEP/NCAR at $5^{\circ} \times 5^{\circ}$ resolution in longitude and latitude. In Figure 6a, the frequency distribution of the differences in $\mathrm{P}_{\mathrm{LRT}}$ between the reanalysis and radiosondes is shown in blue bars. This histogram is based on regridded monthly $\mathrm{P}_{\mathrm{LRT}}$ from all radiosonde records over 1980-2017 with $\sim 130,000$ data points. This histogram is similar to a normal distribution and $\sim 70 \%$ of the $\mathrm{P}_{\mathrm{LRT}}$ biases range between -10 and $10 \mathrm{hPa}$. We first examine a case in which the variable of interest is presented at $1-\mathrm{km}$ vertical resolution. In Figure 6, the solid red line indicates misidentification frequency for a profile at $1-\mathrm{km}$ vertical resolution, which is the number of samples with misidentified tropopause layer divided by the total number of samples in each of the $P_{\text {LRT }}$ bias intervals. If $\mathrm{P}_{\text {LRT }}$ biases are within an interval of $0-5 \mathrm{hPa}$, the ratio is below $10 \%$. The ratio increases with increase of $\mathrm{P}_{\text {LRT }}$ biases. When $\mathrm{P}_{\mathrm{LRT}}$ biases are larger than $40 \mathrm{hPa}$, the ratio reaches $100 \%$, i.e., the tropopause layer is misidentified in all data points. The ratio varies symmetrically with negative $P_{\text {LRT }}$ biases. With a vertical resolution of $0.5 \mathrm{~km}$ (the dashed red line in Figure 6), the ratio becomes larger at a given $P_{\text {LRT }}$ bias and reaches $100 \%$ at a smaller value of $\mathrm{P}_{\mathrm{LRT}}$ bias. Therefore, attention should be paid to the subtropics where absolute $\mathrm{P}_{\text {LRT }}$ biases in the reanalyses are often greater than $10 \mathrm{hPa}$ (Figure 3) and so may cause misidentification of the tropopause layer with probability larger than $40 \%$. Of all samples, the samples with misidentified tropopause layer are $\sim 30 \%$ at $1-\mathrm{km}$ resolution and $\sim 50 \%$ at 0.5-km resolution.

\subsection{Implication of $P_{L R T}$ Biases to TCO Estimates}

TCO is expressed in milli-atmo-centimeters of ozone, or Dobson Units (DU). We can use radiosonde $\mathrm{P}_{\mathrm{LRT}}$ and reanalysis $\mathrm{P}_{\mathrm{LRT}}$ as the upper limit for integration of TCO individually, but keep ozone and pressure profiles the same. Therefore, the difference in TCO (namely TCO bias) from the two ways are caused by the $\mathrm{P}_{\mathrm{LRT}}$ difference between the reanalysis and radiosonde.

We first assess the TCO biases at global ozonesonde stations. Figure 7 shows the mean TCO bias varying with different $P_{\text {LRT }}$ bias intervals in the reanalyses. Here, the reanalysis $P_{\text {LRT }}$ at their original resolutions were used; There are 6423 monthly mean samples in Figure 7a with NCEP/NCAR $\mathrm{P}_{\mathrm{LRT}}$ and 4679 in Figure $7 \mathrm{~b}$ with MERRA-2 $\mathrm{P}_{\mathrm{LRT}}$. A positive bias in $P_{\text {LRT }}$ can induce a negative bias in TCO, while a negative bias in $P_{\text {LRT }}$ can induce a positive bias in TCO. Regardless of the sign of the biases, TCO biases increase with $\mathrm{P}_{\mathrm{LRT}}$ biases, up to $\sim 5 \mathrm{DU}$ with $\mathrm{P}_{\mathrm{LRT}}$ biases of $\sim 40 \mathrm{hPa}$ in absolute values (Figure 7 ). The distribution of occurrence frequency in each of $\mathrm{P}_{\mathrm{LRT}}$ bias intervals is similar to that in Figure 6. Approximately, $85 \%$ of the $\mathrm{P}_{\mathrm{LRT}}$ biases range between -15 and $15 \mathrm{hPa}$. In absolute magnitude, the induced TCO bias is $\sim 0.2, \sim 0.8$ and $\sim 1.2$ DU if the $\mathrm{P}_{\text {LRT }}$ bias is within $0-5$, 10-15, and 10-15 hPa, respectively. Notably, the corresponding standard deviations are larger than the means of TCO biases in the $\mathrm{P}_{\text {LRT }}$ intervals between $-15 \mathrm{hPa}$ and $15 \mathrm{hPa}$. 

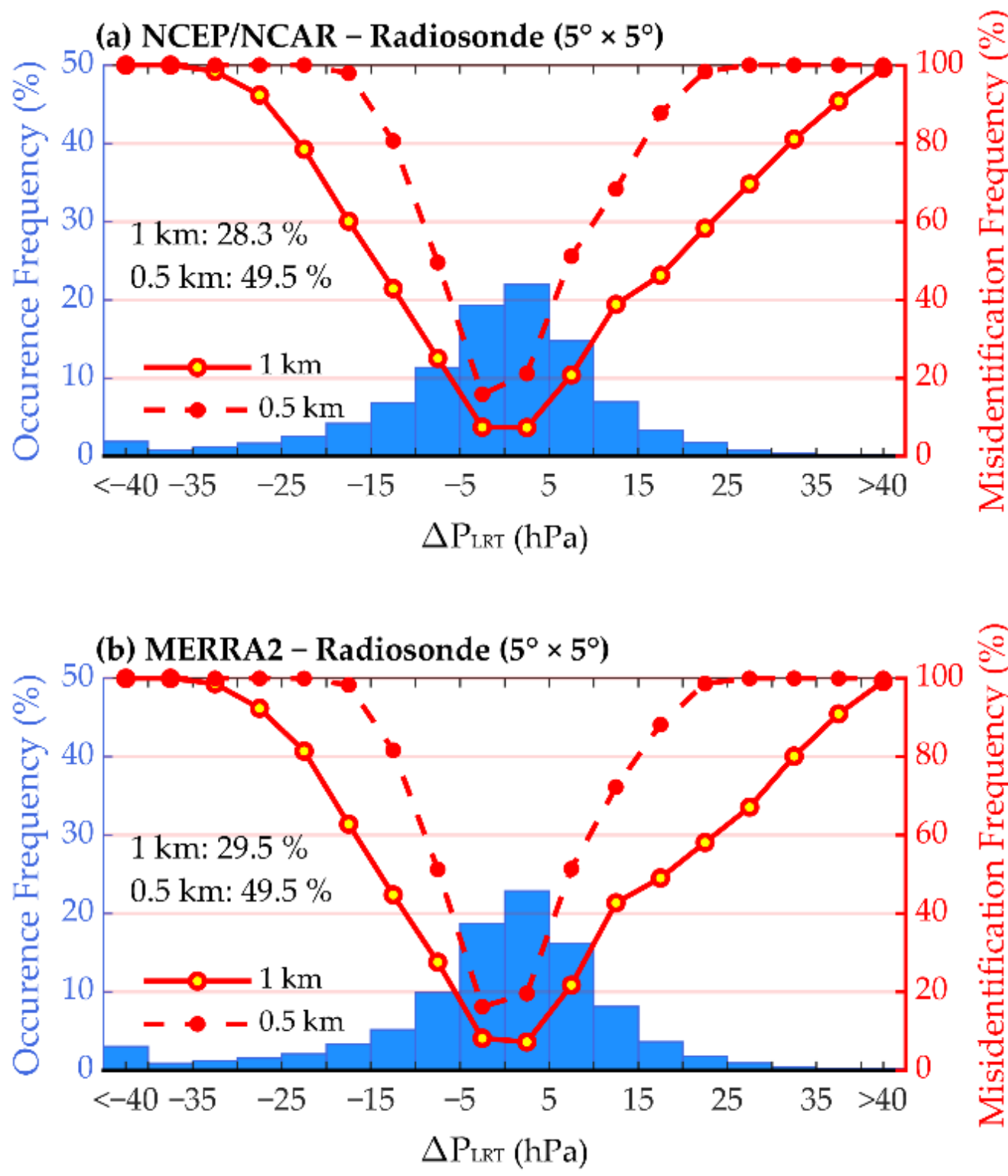

Figure 6. (a) Histogram of the $\mathrm{P}_{\text {LRT }}$ biases in NCEP/NCAR (blue bar, left $y$-axis), based on all monthly samples at all available $5^{\circ} \times 5^{\circ}$ regridded cells containing one or more radiosonde sites over 1980-2017. Ratio (right $y$-axis) of the number of samples with misidentified tropopause layer to the total number of samples in each of the bias intervals ( $x$-axis) at 1-km (red solid line) and $0.5-\mathrm{km}$ (red dashed line) vertical resolutions. The text indicates the ratio of misidentified tropopause layers in NCEP/NCAR based on all monthly samples. (b) The same as (a), but for the $P_{\text {LRT }}$ biases in MERRA-2. The NCEP/NCAR and MERRA-2 data are remapped to a horizontal resolution of $5^{\circ} \times 5^{\circ}$ in longitude and latitude to be consistent with TOST data.

As ozonesonde stations are sparse, we further explore the influence of $P_{\text {LRT }}$ biases on TCO estimates using ozone profiles in TOST. As shown in Section 3.2, $\mathrm{P}_{\text {LRT }}$ biases hardly vary with horizontal resolution. Therefore, we can neglect the influence of horizontal resolution and regrid the two reanalysis $\mathrm{P}_{\mathrm{LRT}}$ datasets into $5^{\circ} \times 5^{\circ}$ in longitude and latitude resolution to match that of TOST. 
(a) NCEP/NCAR $\left(2.5^{\circ} \times 2.5^{\circ}\right)$

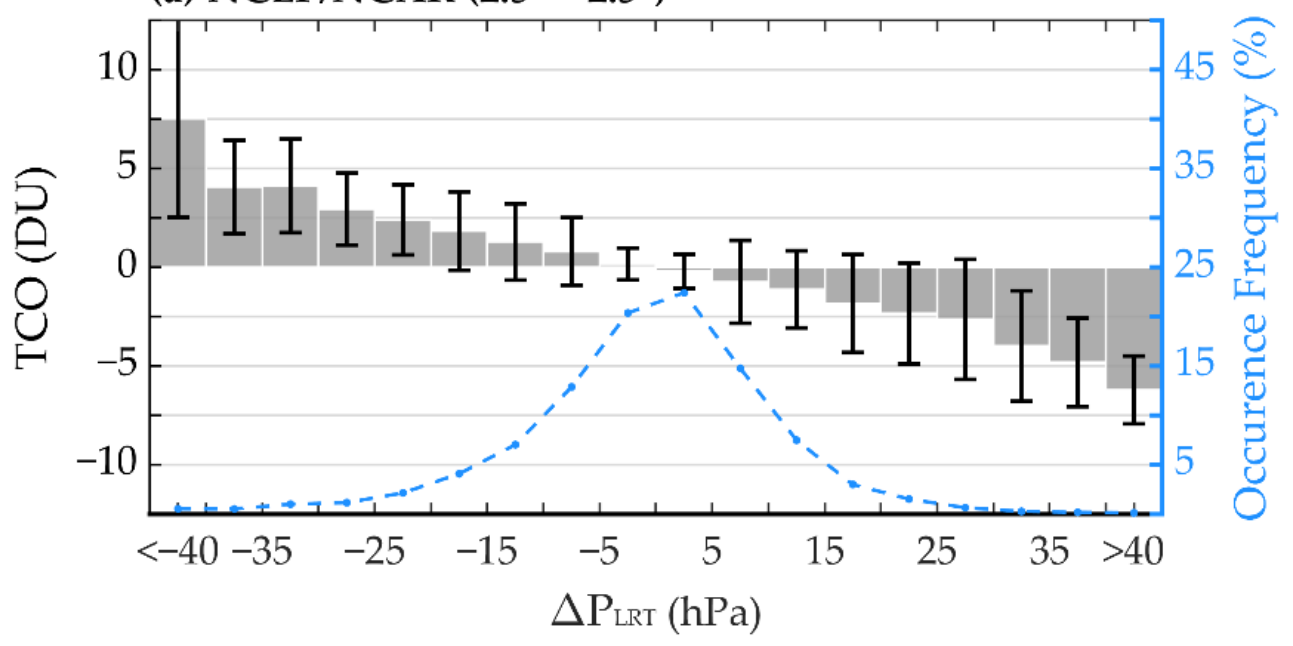

(b) MERRA $\left(0.625^{\circ} \times 0.5^{\circ}\right)$

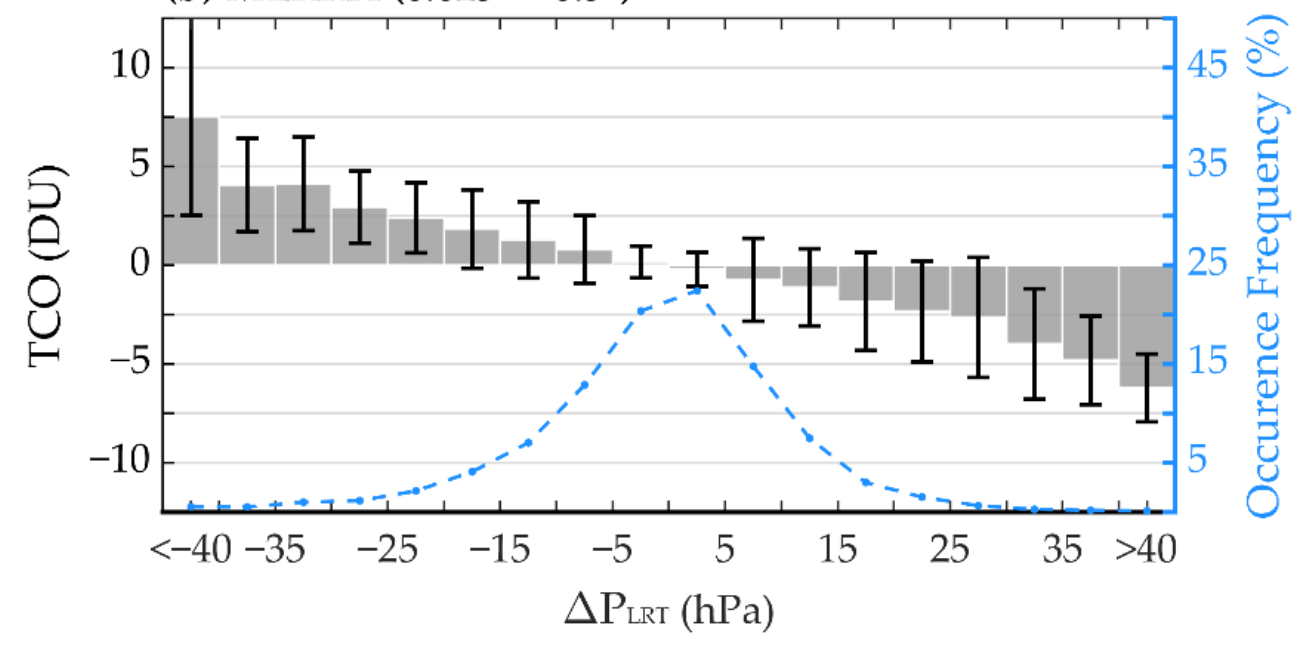

Figure 7. (a) Means (gray bar) and standard deviations (black error bar) of tropospheric column ozone (TCO) biases caused by using NCEP/NCAR $\mathrm{P}_{\text {LRT }}$ in each of the $\mathrm{P}_{\mathrm{LRT}}$ bias intervals (left $y$-axis), based on all monthly samples for which both radiosonde and ozonesonde are available. TCO bias is computed as the difference in TCO using NCEP/NCAR $\mathrm{P}_{\text {LRT }}$ and using radiosonde $\mathrm{P}_{\mathrm{LRT}}$. The occurrence frequency of the NCEP/NCAR $P_{\text {LRT }}$ biases in each of the $P_{\text {LRT }}$ bias intervals is also shown (blue dashed line, right $y$-axis). (b) The same as (a), but for $P_{\text {LRT }}$ biases in MERRA-2 and induced TCO biases. The NCEP/NCAR and MERRA-2 data are used in their original resolutions of $2.5^{\circ} \times 2.5^{\circ}$ and $0.625^{\circ} \times 0.5^{\circ}$ in longitude and latitude.

The global distribution of TCO biases (Figure 8) is basically similar to that of $\mathrm{P}_{\text {LRT }}$ biases (Figure 2), including the latitudinal behavior. Negative biases in TCO prevail in the tropics and the high-latitudes of the $\mathrm{NH}$, with means less than $1 \mathrm{DU}$ in magnitude. TCO in the subtropics is overestimated and the positive TCO biases peak around $30^{\circ}-40^{\circ}$ in each hemisphere with values of $\sim 1.5-3.5 \mathrm{DU}$, corresponding to $\mathrm{P}_{\mathrm{LRT}}$ biases varying from -8 to $-14 \mathrm{hPa}$ (Figure 2). For some grid cells in the subtropics, the positive TCO bias even reaches $4 \mathrm{DU}$ or more, corresponding to a negative $\mathrm{P}_{\mathrm{LRT}}$ bias less than $-20 \mathrm{hPa}$. For the NCEP/NCAR, the overestimation of TCO reaches $\sim 3.5 \mathrm{DU}$ around $70^{\circ}-80^{\circ} \mathrm{S}$, because the extreme $\mathrm{P}_{\mathrm{LRT}}$ biases (about $-20 \mathrm{hPa}$ ) appear there. Overall, the globally averaged bias in TCO due to use of the reanalysis $\mathrm{P}_{\mathrm{LRT}}$ is $0.64 \mathrm{DU}$ in NCEP/NCAR and $0.28 \mathrm{DU}$ in MERRA-2, corresponding to $2.2 \%$ and $1.1 \%$ of average TCO values, respectively. Note that 
TCO values from TOST can be affected by multiple factors, while this study only quantifies the impact of LRT biases in reanalysis products on TOST TCO estimates.

(a) TCO(NCEP/NCAR) - TCO(Radiosonde)

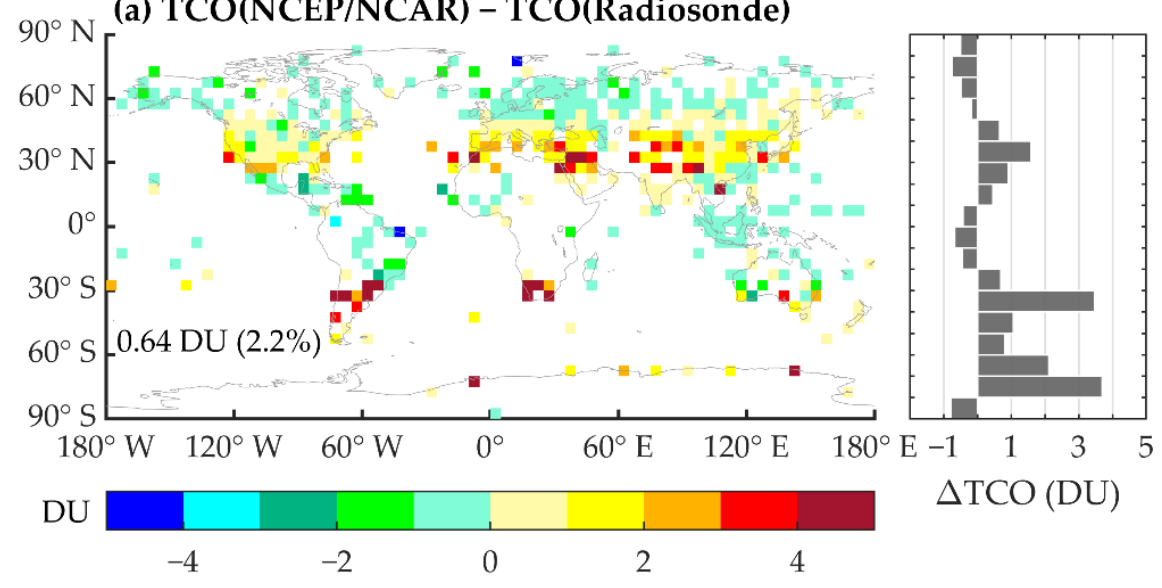

(b) TCO(MERRA2) - TCO(Radiosonde)

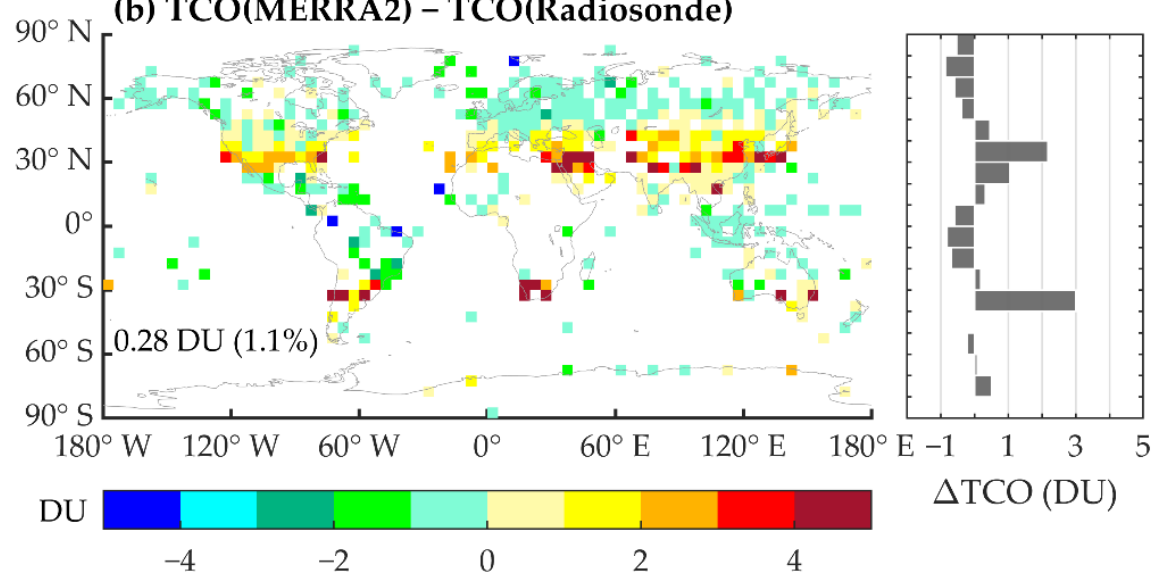

Figure 8. (a) Spatial variation in the TCO biases (in DU) between using NCEP/NCAR $P_{\text {LRT }}$ and using radiosonde $\mathrm{P}_{\mathrm{LRT}}$. Each value is the mean difference in TCO over 1980-2017 at each of the $5^{\circ} \times 5^{\circ}$ grid cells. In the right panels, $10^{\circ}$ zonal-mean differences are shown. The text indicates the global mean bias in absolute and relative terms. (b) The same as (a), but for the TCO biases using MERRA-2 $P_{\text {LRT }}$. Vertical ozone profile data is based on TOST at 1-km resolution. Blank grids are missing data mainly due to unavailability of radiosonde data. Both NCEP/NCAR and MERRA-2 data are remapped to the horizontal resolution of TOST, $5^{\circ} \times 5^{\circ}$ in longitude and latitude [57]. The text in each panel indicates the global mean biases if $\mathrm{P}_{\mathrm{LRT}}$ from the corresponding reanalysis is used.

\section{Discussion and Conclusions}

NCEP/NCAR and MERRA-2 provide $P_{\text {LRT }}$ data directly for many applications. Here, through comparison with radiosonde IGRA2 data over 1980-2017, we have examined spatial and seasonal variations in $\mathrm{P}_{\mathrm{LRT}}$ biases in NCEP/NCAR and MERRA-2 on a monthly basis.

$P_{\text {LRT }}$ biases in the reanalyses vary more with latitude than with longitude (Figure 2). The latitudinal variation averaged over 1980-2017 is characterized by positive biases of $0.5-5.5 \mathrm{hPa}$ in the tropics and high latitudes of the $\mathrm{NH}$ and negative biases of -0.3 to $-14.1 \mathrm{hPa}$ near the subtropics $\left(\sim 20^{\circ}-50^{\circ}\right)$ of each hemisphere in both reanalyses. The large negative $\mathrm{P}_{\mathrm{LRT}}$ biases in the subtropics, corresponding to positive biases in $\mathrm{H}_{\mathrm{LRT}}$ there, are linked to the location of the subtropical jet and tropopause break $[2,19,62]$. A noticeable difference between the two reanalyses is that in high latitudes of the $\mathrm{SH}$, negative $\mathrm{P}_{\mathrm{LRT}}$ biases in NCEP/NCAR are greatly reduced in MERRA-2, possibly owing to including the assimilation of MLS stratospheric ozone profiles and OMI column ozone in MERRA-2. 
Except for $60^{\circ}-90^{\circ} \mathrm{S}$ in NCEP/NCAR and the subtropics in both reanalyses, positive biases prevail and are usually less than $10 \mathrm{hPa}$ at other latitudes. The extreme negative $\mathrm{P}_{\mathrm{LRT}}$ biases of below $-20 \mathrm{hPa}$ appear most frequently around $30^{\circ}-40^{\circ} \mathrm{S}$ in both reanalyses. Approximately, $70 \%$ of the reanalysis $\mathrm{P}_{\mathrm{LRT}}$ biases are within $-10-10 \mathrm{hPa}$ (Figure 3). Taking cosine-weighted latitudinal averages for the globe, we estimate that the global mean $\mathrm{P}_{\mathrm{LRT}}$ bias is about $-2.3 \mathrm{hPa}$ in NCEP/NCAR and $-0.9 \mathrm{hPa}$ in MERRA-2, largely attributable to the large negative $\mathrm{P}_{\mathrm{LRT}}$ biases around the subtropics (Table 1). Correspondingly, the global mean $\mathrm{H}_{\text {LRT }}$ bias is about $52 \mathrm{~m}$ in NCEP/NCAR and $16 \mathrm{~m}$ in MERRA-2. The latitudinal variations in $\mathrm{P}_{\mathrm{LRT}}$ biases in all four seasons are generally similar. However, around the subtropics, the latitudes with the largest negative biases in summer (JJA for the NH, DJF for the $\mathrm{SH}$ ) are shifted $\sim 10^{\circ}$ poleward from the latitudes of winter maximum biases (DJF for the $\mathrm{NH}$, JJA for the $\mathrm{SH}$ ) (Figure 4). Overall, for applications of $\mathrm{P}_{\text {LRT }}$ products, MERRA-2 may be a better choice between the two reanalyses on the global scale, whereas by hemisphere, NCEP/NCAR outperforms MERRA-2 in the NH but underperforms MERRA-2 in the SH.

Two issues relevant to $P_{\text {LRT }}$ biases in applications of reanalysis $P_{\text {LRT }}$ data are investigated. The first one is related to horizontal resolution in the reanalyses. Although $P_{\text {LRT }}$ biases vary little with horizontal resolution, finer horizontal resolution can provide a more detailed variation in grid cell size (Figure 5). Furthermore, caution should be paid to latitudes near the subtropics, as a small mismatch of the grid cell center there can lead to large differences in $\mathrm{P}_{\mathrm{LRT}}$ biases. The second issue is related to identifying the layer of the tropopause in a profile of variable of interest, e.g., ozone or temperature, at different fixed vertical resolutions. The accuracy of such identification depends on both the magnitude of $P_{\text {LRT }}$ bias and the vertical resolution of the profile. Overall, the accuracy decreases with increase of $P_{\text {LRT }}$ bias. When $P_{\text {LRT }}$ biases are above $10 \mathrm{hPa}$ in magnitude, at $1 \mathrm{~km}$ resolution, the misidentification rate exceeds $40 \%$ for both reanalyses (Figure 6 ). Therefore, attention should be paid to the subtropics where the absolute $\mathrm{P}_{\mathrm{LRT}}$ biases in the reanalyses are often more than $10 \mathrm{hPa}$ (Figure 3). The misidentification rate is lower for a vertical profile at $1 \mathrm{~km}$ than at $0.5 \mathrm{~km}$ resolution. Of all radiosonde samples, samples with misidentified tropopause layer are $\sim 30 \%$ at $1-\mathrm{km}$ resolution and $\sim 50 \%$ at $0.5-\mathrm{km}$ resolution (Figure 6 ).

We assess TCO biases that are attributed to $P_{\text {LRT }}$ biases in the reanalyses based on ozone profiles at ozonesonde stations and in TOST. After matching ozonesonde and radiosonde data with the reanlayses at their original horizontal resolutions $\left(2.5^{\circ} \times 2.5^{\circ}\right.$ for NCEP/NCAR and $0.625^{\circ} \times 0.5^{\circ}$ for MERRA-2 in longitude and latitude), we found $\sim 6400$ and $\sim 4700$ monthly ozone profiles for NCEP/NCAR and MERRA-2, respectively. As expected, a positive (negative) bias in $\mathrm{P}_{\mathrm{LRT}}$ leads to a negative (positive) bias in TCO. In absolute magnitude, the induced TCO bias is $\sim 0.2, \sim 0.8$ and $\sim 1.2 \mathrm{DU}$ if the $\mathrm{P}_{\mathrm{LRT}}$ bias is within $0-5,10-15$, and $10-15 \mathrm{hPa}$ (Figure 7). Most of the $\mathrm{P}_{\mathrm{LRT}}$ biases in the reanalyses are less than $15 \mathrm{hPa}$ in absolute magnitude. As TOST ozone data cover the globe, the assessment using TOST provides a detailed description of how the induced TCO biases vary with latitude and longitude. The global distribution of the induced TCO biases (Figure 8) is similar to that of $P_{\text {LRT }}$ biases in the reanalyses (Figure 2). The TCO biases vary much more with latitude than with longitude. Negative biases in TCO prevail in the tropics and high latitudes of the $\mathrm{NH}$, with mean zonal biases less than $1 \mathrm{DU}$ in absolute magnitude. However, positive TCO biases appear in the subtropics and peak around $30^{\circ}-40^{\circ}$ in each hemisphere with values of $1.5-3.5$ DU. For the NCEP/NCAR, negative TCO biases also reach $\sim 3.5 \mathrm{DU}$ around $70^{\circ}-80^{\circ} \mathrm{S}$, because the extreme $\mathrm{P}_{\text {LRT }}$ biases (about $-20 \mathrm{hPa}$ ) appear there. Globally, the mean bias in TCO is estimated to be positive, being $\sim 0.64$ (or $2.2 \%$ ) and $\sim 0.28 \mathrm{DU}$ (or 1.1\%), respectively, if NCEP/NCAR and MERRA-2 $\mathrm{P}_{\text {LRT }}$ products are used in deriving TCO.

This study provides a comprehensive understanding of $P_{\text {LRT }}$ biases in the NCEP/NCAR and MERRA-2, as well as the related biases in TCO estimates. The $P_{\text {LRT }}$ biases could induce biases in other applications, such as estimates of STE mass fluxes, especially near the subtropics where $\mathrm{P}_{\mathrm{LRT}}$ biases are large. This study has assessed the magnitude, sign, and spatial variations in TCO biases attributable to $P_{\text {LRT }}$ biases in the two reanalyses. Such 
assessments have wide implications for studies of tropospheric ozone burden, tropospheric ozone radiative forcing, derivation of TCO from satellite data, and data assimilation. In this study, we select long-term global radiosonde data as a basis for the $\mathrm{P}_{\mathrm{LRT}}$ bias assessment because of the high quality of the data for identifying $\mathrm{P}_{\mathrm{LRT}}$. We employ cosine-weighted latitudinal averaging to minimize the impact of spatial inhomogeneity of radiosonde data on our global and hemispheric assessments of $\mathrm{P}_{\text {LRT }}$ biases. Although it is beyond the scope of this study, $\mathrm{P}_{\text {LRT }}$ from GPS-RO satellite data could be used to enhance our understanding of the global variation in $\mathrm{P}_{\mathrm{LRT}}$ biases for recent decades. Furthermore, what drives biases in tropopause altitude in reanalyses could be further explored for improvement of reanalysis LRT products.

Author Contributions: J.L. conceptualized the research. L.M. conducted the data analysis and prepared the figures and tables under the supervision of J.L., L.M., and J.L wrote the paper with valuable input from D.W.T. and Y.L. D.W.T. thoroughly reviewed the paper. All authors have read and agreed to the published version of the manuscript.

Funding: This research was funded by the Chinese Ministry of Science and Technology National Key R\&D Program of China (grant nos. 2019YFA0606803 and 2016YFA0600204).

Institutional Review Board Statement: Not applicable.

Informed Consent Statement: Not applicable.

Data Availability Statement: NCEP/NCAR products are openly provided by the NOAA/OAR/ESRL PSL, Boulder, Colorado, USA, from their Web site at https:/ / psl.noaa.gov/ (accessed on 25 September 2020). MERRA-2 products are openly provided by the National Aeronautics and Space Administration (NASA) Global Modeling and Assimilation Office (GMAO), available online: https: / / disc.sci.gsfc.nasa.gov / (accessed on 19 February 2019). The radiosonde observations are openly provided by the National Oceanic and Atmospheric Administration (NOAA) National Centers for Environ-mental Information (NCEI), available online: https:/ / www.ncdc.noaa.gov / (accessed on 12 September 2018). The global ozone sounding data are openly provided by the World Ozone and Ultraviolet Radiation Data Centre (WOUDC), available online: http:/ / www.woudc.org/ (accessed on 26 October 2017).

Acknowledgments: The authors thank the agencies that provided reanalysis data used in this study: NCEP/NCAR from the NOAA/OAR/ESRL PSL, Boulder, Colorado, USA and MERRA-2 from the National Aeronautics and Space Administration (NASA) Global Modeling and Assimilation Office (GMAO). We also thank the National Oceanic and Atmospheric Administration (NOAA) National Centers for Environmental Information (NCEI) for providing IGRA radiosonde data. The global ozone sounding data were obtained from the World Ozone and Ultraviolet Radiation Data Centre (WOUDC) operated by Environment Canada, Toronto, Ontario, Canada, under the auspices of the World Meteorological Organization. We acknowledge the Max Plank Institute for Meteorology (MPIM) for providing the CDO software (https: / / code.mpimet.mpg.de/projects/cdo/ files (accessed on 14 October 2020)) and many contributors to the CDO development. We would like to thank the anonymous reviewers for their valuable comments and suggestions.

Conflicts of Interest: The authors declare no conflict of interest.

\section{Appendix A}

Table A1. The total number of stations and soundings that are used for calculating monthly radiosonde $P_{\text {LRT }}$ under different thresholds where daily $P_{\text {LRT }}$ values are available on at least 5, 10, 15, or 20 days in a month.

\begin{tabular}{ccccc}
\hline Thresholds & 5 Days & 10 Days & 15 Days & 20 Days \\
\hline Soundings & 203,203 & 190,304 & 174,285 & 148,643 \\
Stations & 714 & 705 & 689 & 673 \\
\hline
\end{tabular}




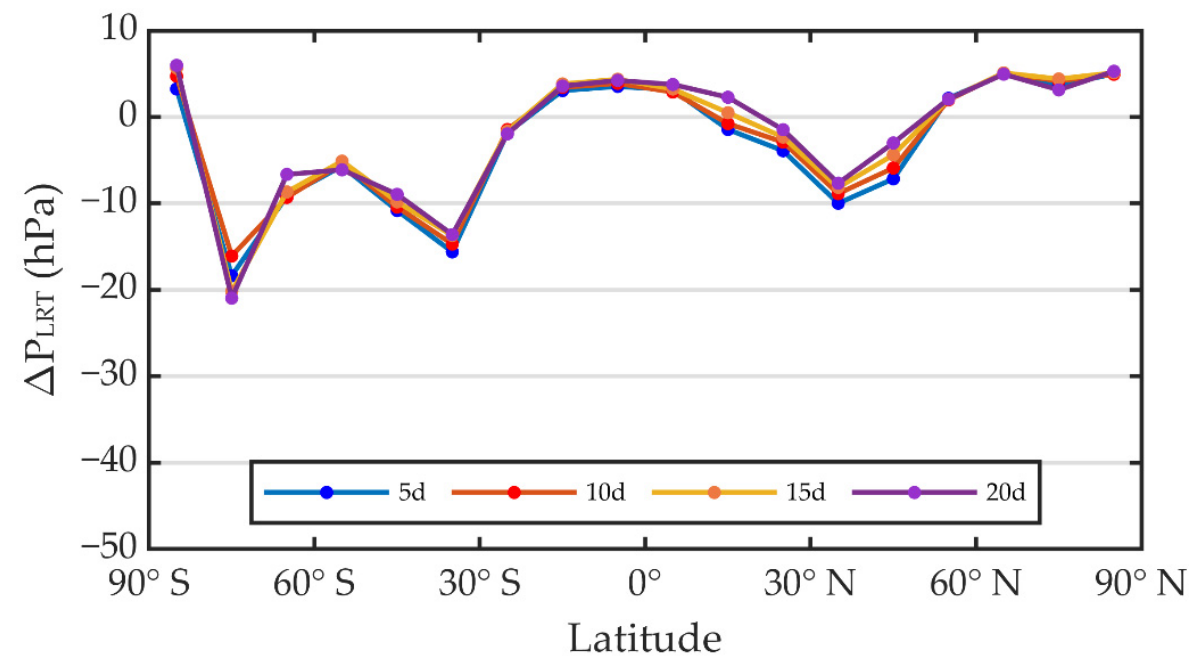

Figure A1. Latitudinal variation in monthly $\mathrm{P}_{\mathrm{LRT}}$ difference $\left(\triangle \mathrm{P}_{\mathrm{LRT}}\right.$, in $\left.\mathrm{hPa}\right)$ between NCEP/NCAR reanalysis and radiosonde data averaged over 1980-2017. The monthly radiosonde $\mathrm{P}_{\mathrm{LRT}}$ is calculated with different thresholds that requires at least 5, 10, 15, or 20 days with available daily radiosonde $\mathrm{P}_{\mathrm{LRT}}$ in a month. The data showed is the $10^{\circ}$-zonal mean.

\section{References}

1. Santer, B.D.; Wehner, M.F.; Wigley, T.M.L.; Sausen, R.; Meehl, G.A.; Taylor, K.E.; Ammann, C.; Arblaster, J.; Washington, W.M.; Boyle, J.S.; et al. Contributions of anthropogenic and natural forcing to recent tropopause height changes. Science 2003, 301, 479-483. [CrossRef] [PubMed]

2. Santer, B.D.; Sausen, R.; Wigley, T.M.L.; Boyle, J.S.; AchutaRao, K.M.; Doutriaux, C.; Hansen, J.E.; Meehl, G.A.; Roeckner, E.; Ruedy, R.; et al. Behavior of tropopause height and atmospheric temperature in models, reanalyses, and observations: Decadal changes. J. Geophys. Res. Space Phys. 2003, 108. [CrossRef]

3. Santer, B.D.; Wigley, T.M.L.; Simmons, A.J.; Kållberg, P.W.; Kelly, G.A.; Uppala, S.M.; Ammann, C.; Boyle, J.S.; Brüggemann, W.; Doutriaux, C.; et al. Identification of anthropogenic climate change using a second-generation reanalysis. J. Geophys. Res. Space Phys. 2004, 109. [CrossRef]

4. Lucas, C.; Timbal, B.; Nguyen, H. The expanding tropics: A critical assessment of the observational and modeling studies. Wiley Interdiscip. Rev. Clim. Chang. 2014, 5, 89-112. [CrossRef]

5. Holton, J.R.; Haynes, P.H.; McIntyre, M.E.; Douglass, A.R.; Rood, R.B.; Pfister, L. Stratosphere-troposphere exchange. Rev. Geophys. 1995, 33, 403-439. [CrossRef]

6. $\quad$ Eyring, V.; Butchart, N.; Waugh, D.W.; Akiyoshi, H.; Austin, J.; Bekki, S.; Bodeker, G.E.; Boville, B.A.; Bruhl, C.; Chipper-field, M.P.; et al. Assessment of temperature, trace species, and ozone in chemistry-climate model sim-ulations of the recent past. J. Geophys. Res. Atmos. 2006, 111, D22. [CrossRef]

7. Fueglistaler, S.; Dessler, A.E.; Dunkerton, T.J.; Folkins, I.; Fu, Q.; Mote, P.W. Tropical tropopause layer. Rev. Geophys. 2009, 47, 47. [CrossRef]

8. Sullivan, J.T.; McGee, T.J.; Thompson, A.M.; Pierce, R.B.; Sumnicht, G.K.; Twigg, L.W.; Eloranta, E.; Hoff, R.M. Characterizing the lifetime and occurrence of stratospheric-tropospheric exchange events in the rocky mountain region using high-resolution ozone measurements. J. Geophys. Res. Atmos. 2015, 120, 12410-12424. [CrossRef]

9. Boothe, A.C.; Homeyer, C.R. Global large-scale stratosphere-troposphere exchange in modern reanalyses. Atmos. Chem. Phys. Discuss. 2017, 17, 5537-5559. [CrossRef]

10. Di Noia, A.; Sellitto, P.; Del Frate, F.; De Laat, J. Global tropospheric ozone column retrievals from OMI data by means of neural networks. Atmos. Meas. Tech. 2013, 6, 895-915. [CrossRef]

11. Gaudel, A.; Cooper, O.R.; Ancellet, G.; Barret, B.; Boynard, A.; Burrows, J.P.; Clerbaux, C.; Coheur, P.-F.; Cuesta, J.; Cuevas, E.; et al. Tropospheric Ozone Assessment Report: Present-day distribution and trends of tropospheric ozone relevant to climate and global atmospheric chemistry model evaluation. Elem. Sci. Anth. 2018, 6, 39. [CrossRef]

12. Wang, C.-Y.; Xie, S.-P.; Kosaka, Y.; Liu, Q.; Zheng, X.-T. Global Influence of Tropical Pacific Variability with Implications for Global Warming Slowdown. J. Clim. 2017, 30, 2679-2695. [CrossRef]

13. Ridley, D.A.; Solomon, S.; Barnes, J.E.; Burlakov, V.D.; Deshler, T.; Dolgii, S.I.; Herber, A.B.; Nagai, T.; Neely, R.R.; Nevzorov, A.V.; et al. Total volcanic stratospheric aerosol optical depths and implications for global climate change. Geophys. Res. Lett. 2014, 41, 7763-7769. [CrossRef]

14. Friberg, J.; Martinsson, B.G.; Andersson, S.M.; Sandvik, O.S. Volcanic impact on the climate-The stratospheric aerosol load in the period 2006-2015. Atmos. Chem. Phys. Discuss. 2018, 18, 11149-11169. [CrossRef] 
15. Wild, O. Modelling the global tropospheric ozone budget: Exploring the variability in current models. Atmos. Chem. Phys. Discuss. 2007, 7, 2643-2660. [CrossRef]

16. Prather, M.J.; Zhu, X.; Tang, Q.; Hsu, J.; Neu, J.L. An atmospheric chemist in search of the tropopause. J. Geophys. Res. Space Phys. 2011, 116. [CrossRef]

17. Stevenson, D.S.; Young, P.J.; Naik, V.; Lamarque, J.-F.; Shindell, D.T.; Voulgarakis, A.; Skeie, R.B.; Dalsoren, S.B.; Myhre, G.; Berntsen, T.K.; et al. Tropospheric ozone changes, radiative forcing and attribution to emissions in the Atmospheric Chemistry and Climate Model Intercomparison Project (ACCMIP). Atmos. Chem. Phys. Discuss. 2013, 13, 3063-3085. [CrossRef]

18. WMO. Meteorology: A three-dimensional science: Second session of the Commission for Aerology. WMO Bull. 1957, 4, 134-138.

19. Schmidt, T.; Wickert, J.; Beyerle, G.; Heise, S. Global tropopause height trends estimated from GPS radio occultation data. Geophys. Res. Lett. 2008, 35. [CrossRef]

20. Highwood, E.J.; Hoskins, B.J. The tropical tropopause (vol 124, pg 1579, 1998). Q. J. R. Meteorol. Soc. 1998, $124,2536$.

21. Randel, W.J.; Wu, F.; Oltmans, S.J.; Rosenlof, K.; Nedoluha, G.E. Interannual changes of stratospheric water vapor and correlations with tropical tropopause temperatures. J. Atmos. Sci. 2004, 61, 2133-2148. [CrossRef]

22. Kuang, S.; Newchurch, M.J.; Burris, J.; Wang, L.; Knupp, K.; Huang, G. Stratosphere-to-troposphere transport revealed by ground-based lidar and ozonesonde at a midlatitude site. J. Geophys. Res. Space Phys. 2012, 117. [CrossRef]

23. Kunz, A.; Sprenger, M.; Wernli, H. Climatology of potential vorticity streamers and associated isentropic transport pathways across PV gradient barriers. J. Geophys. Res. Atmos. 2015, 120, 3802-3821. [CrossRef]

24. Sivakumar, V.; Bencherif, H.; Bègue, N.; Thompson, A.M. Tropopause Characteristics and Variability from 11 yr of SHA-DOZ Observations in the Southern Tropics and Subtropics. J. Appl. Meteorol. Climatol. 2011, 50, 1403-1416. [CrossRef]

25. Randel, W.J.; Seidel, D.J.; Pan, L.L. Observational characteristics of double tropopauses. J. Geophys. Res. Space Phys. $2007,112$. [CrossRef]

26. Pan, L.L.; Honomichl, S.B.; Bui, T.V.; Thornberry, T.; Rollins, A.; Hintsa, E.; Jensen, E.J. Lapse Rate or Cold Point: The Tropical Tropopause Identified by In Situ Trace Gas Measurements. Geophys. Res. Lett. 2018, 45, 10-756-10-763. [CrossRef]

27. Zängl, G.; Hoinka, K.P. The Tropopause in the Polar Regions. J. Clim. 2001, 14, 3117-3139. [CrossRef]

28. Seidel, D.J.; Randel, W.J. Variability and trends in the global tropopause estimated from radiosonde data. J. Geophys. Res. Space Phys. 2006, 111. [CrossRef]

29. Son, S.-W.; Tandon, N.F.; Polvani, L.M. The fine-scale structure of the global tropopause derived from COSMIC GPS radio occultation measurements. J. Geophys. Res. Space Phys. 2011, 116. [CrossRef]

30. Wang, W.; Matthes, K.; Schmidt, T.; Neef, L. Recent variability of the tropical tropopause inversion layer. Geophys. Res. Lett. 2013, 40, 6308-6313. [CrossRef]

31. Li, W.; Yuan, Y.-B.; Chai, Y.-J.; Liou, Y.-A.; Ou, J.-K.; Zhong, S.-M. Characteristics of the global thermal tropopause derived from multiple radio occultation measurements. Atmos. Res. 2017, 185, 142-157. [CrossRef]

32. Hoinka, K.P. Statistics of the Global Tropopause Pressure. Mon. Weather. Rev. 1998, 126, 3303-3325. [CrossRef]

33. Xie, F.; Li, J.; Tian, W.; Feng, J.; Huo, Y. Signals of El Niño Modoki in the tropical tropopause layer and stratosphere. Atmospheric Chem. Phys. Discuss. 2012, 12, 5259-5273. [CrossRef]

34. Zerefos, C.S.; Tourpali, K.; Zanis, P.; Eleftheratos, K.; Repapis, C.; Goodman, A.; Wuebbles, D.; Isaksen, I.S.A.; Luterbacher, J. Evidence for an earlier greenhouse cooling effect in the stratosphere before 1980 over the Northern Hemisphere. Atmos. Chem. Phys. Discuss. 2014, 14, 7705-7720. [CrossRef]

35. Hess, P.G.; Lamarque, J.-F. Ozone source attribution and its modulation by the Arctic oscillation during the spring months. J. Geophys. Res. Space Phys. 2007, 112. [CrossRef]

36. Fitzka, M.; Hadzimustafic, J.; Simic, S. Total ozone and Umkehr observations at Hoher Sonnblick 1994-2011: Climatology and extreme events. J. Geophys. Res. Atmos. 2014, 119, 739-752. [CrossRef]

37. Kalnay, E.; Kanamitsu, M.; Kistler, R.; Collins, W.; Deaven, D.; Gandin, L.; Iredell, M.; Saha, S.; White, G.; Woollen, J.; et al. The NCEP/NCAR 40-year reanalysis project. Bull. Am. Meteorol. Soc. 1996, 77, 437-471. [CrossRef]

38. Birner, T.; Dörnbrack, A.; Schumann, U. How sharp is the tropopause at midlatitudes? Geophys. Res. Lett. 2002, 29, 45-1-45-4. [CrossRef]

39. Birner, T. Fine-scale structure of the extratropical tropopause region. J. Geophys. Res. Space Phys. 2006, 111. [CrossRef]

40. Xian, T.; Homeyer, C.R. Global tropopause altitudes in radiosondes and reanalyses. Atmos. Chem. Phys. Discuss. 2019, 19, 5661-5678. [CrossRef]

41. Tegtmeier, S.; Anstey, J.; Davis, S.; Dragani, R.; Harada, Y.; Ivanciu, I.; Pilch Kedzierski, R.; Krüger, K.; Legras, B.; Long, C.; et al. Temperature and tropopause characteristics from reanalyses data in the tropical trop-opause layer. Atmos. Chem. Phys. 2020, 20, 753-770. [CrossRef]

42. Randel, W.J.; Gaffen, D.J.; Wu, F. Interannual variability of the tropical tropopause derived from radiosonde data and NCEP reanalyses. J. Geophys. Res. Space Phys. 2000, 105, 15509-15523. [CrossRef]

43. Luan, L.; Staten, P.W.; Ao, C.O.; Fu, Q. Seasonal and Annual Changes of the Regional Tropical Belt in GPS-RO Measure-ments and Reanalysis Datasets. J. Clim. 2020, 33, 4083-4094. [CrossRef]

44. Fishman, J.; Watson, C.E.; Larsen, J.C.; Logan, J.A. Distribution of tropospheric ozone determined from satellite data. J. Geophys. Res. Space Phys. 1990, 95, 3599. [CrossRef] 
45. Ziemke, J.R.; Chandra, S.; Duncan, B.N.; Froidevaux, L.; Bhartia, P.K.; Levelt, P.F.; Waters, J.W. Tropospheric ozone determined from aura OMI and MLS: Evaluation of measurements and comparison with the Global Modeling Initiative's Chemical Transport Model. J. Geophys. Res.-Atmos. 2006, 111, D19. [CrossRef]

46. Young, P.J.; Archibald, A.T.; Bowman, H.; Lamarque, J.-F.; Naik, V.; Stevenson, D.S.; Tilmes, S.; Voulgarakis, A.; Wild, O.; Bergmann, D.; et al. Pre-industrial to end 21st century projections of tropospheric ozone from the Atmospheric Chemistry and Climate Model Intercomparison Project (ACCMIP). Atmos. Chem. Phys. Discuss. 2013, 13, 2063-2090. [CrossRef]

47. Young, P.J.; Naik, V.; Fiore, A.M.; Gaudel, A.; Guo, J.; Lin, M.Y.; Neu, J.L.; Parrish, D.D.; Rieder, H.E.; Schnell, J.L.; et al. Tropospheric Ozone Assessment Report: Assessment of global-scale model performance for global and regional ozone distributions, variability, and trends. Elem. Sci. Anth. 2018, 6. [CrossRef]

48. Griffiths, P.T.; Murray, L.T.; Zeng, G.; Archibald, A.T.; Emmons, L.K.; Galbally, I.; Hassler, B.; Horowitz, L.W.; Keeble, J.; Liu, J.; et al. Tropospheric ozone in CMIP6 Simulations. Atmos. Chem. Phys. Discuss. 2020, under review.

49. Emili, E.; Barret, B.; Massart, S.; Le Flochmoen, E.; Piacentini, A.; El Amraoui, L.; Pannekoucke, O.; Cariolle, D. Combined assimilation of IASI and MLS observations to constrain tropospheric and stratospheric ozone in a global chemical transport model. Atmos. Chem. Phys. Discuss. 2014, 14, 177-198. [CrossRef]

50. Durre, I.; Vose, R.S.; Yin, X.; Applequist, S.; Arnfield, J. Integrated Global Radiosonde Archive (IGRA) Version 2. NOAA Natl. Centers Environ. Inf. 2016, 10, V5X63X0Q. [CrossRef]

51. Gelaro, R.; Mccarty, W.; Suárez, M.J.; Todling, R.; Molod, A.; Takacs, L.; Randles, C.A.; Darmenov, A.; Bosilovich, M.G.; Reichle, R.; et al. The Modern-Era Retrospective Analysis for Research and Applications, Version 2 (MERRA-2). J. Clim. 2017, 30, 5419-5454. [CrossRef] [PubMed]

52. Putman, W.M.; Lin, S.-J. Finite-volume transport on various cubed-sphere grids. J. Comput. Phys. 2007, 227, 55-78. [CrossRef]

53. Birner, T. Recent widening of the tropical belt from global tropopause statistics: Sensitivities. J. Geophys. Res. Space Phys. 2010, 115. [CrossRef]

54. Evtushevsky, O.M.; Grytsai, A.V.; Klekociuk, A.R.; Milinevsky, G.P. Total ozone and tropopause zonal asymmetry during the Antarctic spring. J. Geophys. Res. Space Phys. 2008, 113. [CrossRef]

55. Fujiwara, M.; Wright, J.S.; Manney, G.L.; Gray, L.J.; Anstey, J.; Birner, T.; Davis, S.; Gerber, E.P.; Harvey, V.L.; Hegglin, M.I.; et al. Introduction to the SPARC Reanalysis Intercomparison Project (S-RIP) and overview of the reanalysis systems. Atmos. Chem. Phys. Discuss. 2017, 17, 1417-1452. [CrossRef]

56. Liu, G.; Liu, J.; Tarasick, D.W.; Fioletov, V.E.; Jin, J.J.; Moeini, O.; Liu, X.; Sioris, C.E.; Osman, M. A global tropospheric ozone climatology from trajectory-mapped ozone soundings. Atmos. Chem. Phys. Discuss. 2013, 13, 10659-10675. [CrossRef]

57. Liu, J.; Tarasick, D.W.; Fioletov, V.E.; McLinden, C.; Zhao, T.; Gong, S.; Sioris, C.; Jin, J.J.; Liu, G.; Moeini, O. A global ozone climatology from ozone soundings via trajectory mapping: A stratospheric perspective. Atmos. Chem. Phys. Discuss. 2013, 13, 11441-11464. [CrossRef]

58. Liu, Y.; Xu, T.; Liu, J. Characteristics of the seasonal variation of the global tropopause revealed by COSMIC/GPS data. Adv. Space Res. 2014, 54, 2274-2285. [CrossRef]

59. Davis, S.M.; Hegglin, M.I.; Fujiwara, M.; Dragani, R.; Harada, Y.; Kobayashi, C.; Long, C.; Manney, G.L.; Nash, E.R.; Potter, G.L.; et al. Assessment of upper tropospheric and stratospheric water vapor and ozone in reanalyses as part of S-RIP. Atmos. Chem. Phys. Discuss. 2017, 17, 12743-12778. [CrossRef] [PubMed]

60. Wargan, K.; Labow, G.; Frith, S.; Pawson, S.; Livesey, N.; Partyka, G. Evaluation of the Ozone Fields in NASA's MERRA-2 Reanalysis. J. Clim. 2017, 30, 2961-2988. [CrossRef]

61. Manney, G.L.; Hegglin, M.I.; Lawrence, Z.D.; Wargan, K.; Millán, L.F.; Schwartz, M.J.; Santee, M.L.; Lambert, A.; Pawson, S.; Knosp, B.W.; et al. Reanalysis comparisons of upper tropospheric-lower stratospheric jets and multiple tropopauses. Atmos. Chem. Phys. 2017, 17, 11541-11566. [CrossRef] [PubMed]

62. Homeyer, C.R.; Bowman, K.P.; Pan, L.L. Extratropical tropopause transition layer characteristics from high-resolution sounding data. J. Geophys. Res. Space Phys. 2010, 115. [CrossRef] 